\title{
CHANGES IN THE PHYSICAL SETTING OF OPEN SPACE IN ACCOMMODATING A VARIETY OF ACTIVITIES IN THE CREATIVE KAMPONG OF DAGO POJOK
}

\author{
${ }^{1}$ Priska Ivena. ${ }^{2}$ Dr. Ir. Y. Basuki Dwisusanto, M.Sc. \\ ${ }^{1}$ Student in the Bachelor's (S-1) Study Program in Architecture \\ at Parahyangan Catholic University \\ ${ }^{2}$ Senior lecturer in the Bachelor's (S-1) Study Program in Architecture \\ at Parahyangan Catholic University
}

\begin{abstract}
The development of a given settlement or residential area cannot be detached from the phenomenon of the urban kampong succeeding in holding out, based on the concept of harmoniously living together as members of a community in society, and one of the strategies used is keeping a close-knit community. The city of Bandung with its concept of being a creative city supports the idea of having creative kampongs that promote the arts and culture of the local community. The creative kampong is expected to be able to provide solutions by creating a better environment, and one of these solutions is exploiting the potential of the natural and human resources available to improve the local community's welfare. The aim of this research study is to determine how exactly the community living in the creative kampong of Dago Pojok has been able to enhance the physical setting of a limited amount of space in such creative ways to fulfill the need for a range of activities. The method used for this research project can be classified as qualitative by way of frequent mapping of the physical setting at the creative location selected, based on the outcome of observation and recommendations made by the actual initiator of the creative kampong. This stage was followed by mapping of activities and behavior or attitude in the area under observation over a certain period of time. In order to find out more about the physical setting during incidental activities, the data were obtained from the documentation of the creative kampong. The processed data were subsequently analyzed to determine to which degree the need for activities in a particular physical setting can be attempted by way of creative aspects. In the open space used for everyday activities and creative pursuits, the physical setting initially influenced the activities themselves, and the varied activities went on to provide a context for creativity in the same manner as a physical setting experiences change in keeping with the need for space. The physical elements that undergo change may be categorized as fixed, semi-fixed, and non-fixed elements, and those situated in the open (public) space may be classified as base plane, vertical plane, street accessories, illumination and the scope-related atmosphere.
\end{abstract}

Keywords: change in physical setting, open space, creative kampong, Dago Pojok Kampong

\footnotetext{
${ }^{1}$ Corresponding author: priskaivena@gmail.com
} 


\title{
PERUBAHAN SETTING FISIK RUANG TERBUKA DALAM MEWADAHI BERBAGAI AKTIVITAS DI KAMPUNG KREATIF DAGO POJOK
}

\author{
${ }^{1}$ Priska Ivena. ${ }^{2}$ Dr. Ir. Y. Basuki Dwisusanto, M.Sc. \\ ${ }^{1}$ Mahasiswi S1 Program Studi Arsitektur Universitas Katolik Parahyangan. \\ ${ }^{2}$ Dosen Pembimbing S1 Program Studi Arsitektur Universitas Katolik Parahyangan.
}

\begin{abstract}
Abstrak- Perkembangan permukiman tidak terlepas dari fenomena kampung-kota yang tetap bertahan dengan konsep hidup bersama dalam masyarakat, salah satunya dengan mempertahankan komunitas. Kota Bandung dengan konsep kota kreatif mendukung gagasan adanya kampung kreatif yang mengangkat seni dan budaya masyarakat lokal. Kampung kreatif diharapkan mampu membawa solusi dalam menciptakan lingkungan yang lebih baik, salah satunya dengan memanfaatkan potensi sumber daya alam dan manusia yang ada untuk memajukan kesejahteraan masyarakat. Tujuan dari penelitian ini adalah mengetahui bagaimana masyarakat Kampung Kreatif Dago Pojok dapat mengolah secara kreatif setting fisik sebuah ruang yang terbatas untuk memenuhi kebutuhan aktivitas yang beragam. Metode yang digunakan pada penelitian ini adalah kualitatif dengan melakukan pemetaan setting fisik pada titik lokasi kreatif yang dipilih berdasarkan hasil pengamatan dan rekomendasi dari pihak inisiator kampung kreatif. Kemudian dilanjutkan dengan pemetaan aktivitas dan perilaku berulang pada area amatan yang dilakukan pada periode tertentu. Adapun untuk mengetahui setting fisik pada kegiatan insidental, data diperoleh dari dokumentasi kampung kreatif. Data yang dikumpulkan kemudian dianalisis bagaimana kebutuhan aktivitas akan sebuah setting fisik dapat diupayakan melalui aspek kreatif. Pada ruang terbuka yang digunakan untuk kegiatan sehari-hari dan kegiatan kreatif, setting fisik awal mempengaruhi adanya aktivitas, dan aktivitas yang beragam kemudian memunculkan kreativitas bagaimana sebuah setting fisik mengalami perubahan seiring kebutuhan akan sebuah ruang. Elemen fisik yang dapat mengalami perubahan dapat dikategorikan sebagai elemen fixed, semi-fixed, dan non-fixed, yang pada ruang terbuka dapat berupa base plane, vertical plane, perabot jalan, pencahayaan, dan suasana keterlingkupan.
\end{abstract}

Kata kunci: perubahan setting fisik, ruang terbuka, kampung kreatif, Kampung Dago Pojok

\section{PENDAHULUAN}

Kampung-kota terus berkembang di tengah keberadaan kota yang semakin modern. Kepadatan fisik permukiman, pola dan tatanan fisik serta ruang komunal yang ada mencerminkan budaya masyarakat dengan solidaritas yang tinggi. Keberadaan kampung-kota erat kaitannya dengan pembentukan komunitas, salah satunya diupayakan dengan adanya kampung kreatif yang mempertahankan seni budaya masyarakat.

Kampung Dago Pojok merupakan kampung kreatif pertama yang diresmikan pemerintah Kota Bandung dalam upaya menciptakan konsep kota kreatif. Diinisiasi oleh seorang seniman yang peduli terhadap perkembangan pendidikan dan kebudayaan, Bapak Rahmat Jabaril, Kampung Dago Pojok kini menjadi kampung kreatif dimana masyarakat dapat mengenal diri dan potensi untuk dapat mengembangkan permukiman yang berkelanjutan. Berbeda dengan kampungkota pada umumnya, Kampung Dago Pojok memiliki kekhasan baik secara fisik kampung yang sudah tersentuh elemen seni, maupun secara sosial budaya.

Sebagai sebuah komunitas, masyarakat memiliki aktivitas-aktivitas bersama yang membudaya. Aktivitas masyarakat dibedakan menjadi aktivitas sehari-hari dan aktivitas khusus 
yang sifatnya insidental, seperti pertunjukkan, festival, workshop, pelatihan, penerimaan tamu, sekolah gang, ulin day, dsb. Aktivitas tersebut menjadi kompleks dan perlu diwadahi oleh tatanan fisik ruang terbuka yang seringkali menemukan kondisi yang tidak ideal seperti keterbatasan lahan yang menuntut masyarakat untuk dapat mengelola ruang terbuka secara maksimal. Dalam proses pembentukkan kampung kreatif, terjadi perubahan elemen fisik yang seiring berjalannya waktu memberikan dampak positif bagi kondisi ekonomi, sosial dan budaya masyarakat, seperti keberadaan mural di dinding bahkan permukaan base plane gang yang membangkitkan semangat dan rasa memiliki dalam memelihara lingkungan kampung.

Meninjau bagaimana kreativitas dapat menumbuhkan gagasan dalam mengolah ruang, maka muncul pertanyaan penelitian bagaimana perubahan setting fisik ruang terbuka diupayakan untuk mewadahi aktivitas keseharian masyarakat dan insidental, dimana di dalamnya terdapat aktivitas kreatif. Upaya kreatif masyarakat tercermin melalui peningkatan kualitas ruang seiring kebutuhan masyarakat yang terus berkembang.

Penelitian dilakukan dengan metode kualitatif deskriptif dengan melakukan observasi lapangan terkait perubahan yang terjadi pada beberapa ruang terbuka yang digunakan untuk kegiatan kreatif. Empat buah ruang terbuka dipilih berdasarkan pengamatan dan rekomendasi inisiator. Pemetaan pada setting fisik tiap titik lokasi kreatif dilanjutkan dengan pemetaan aktivitas dan perilaku berulang pada area amatan (metode place-centered mapping). Penelitian dilakukan pada periode I (pukul 07.00-11.00), periode II (pukul 11.00-14.00), periode III (pukul 14.00-18.00), periode IV (pukul 18.00-20.00). Adapun untuk mengetahui setting pada saat aktivitas insidental, data diperoleh dari dokumentasi kampung kreatif. 


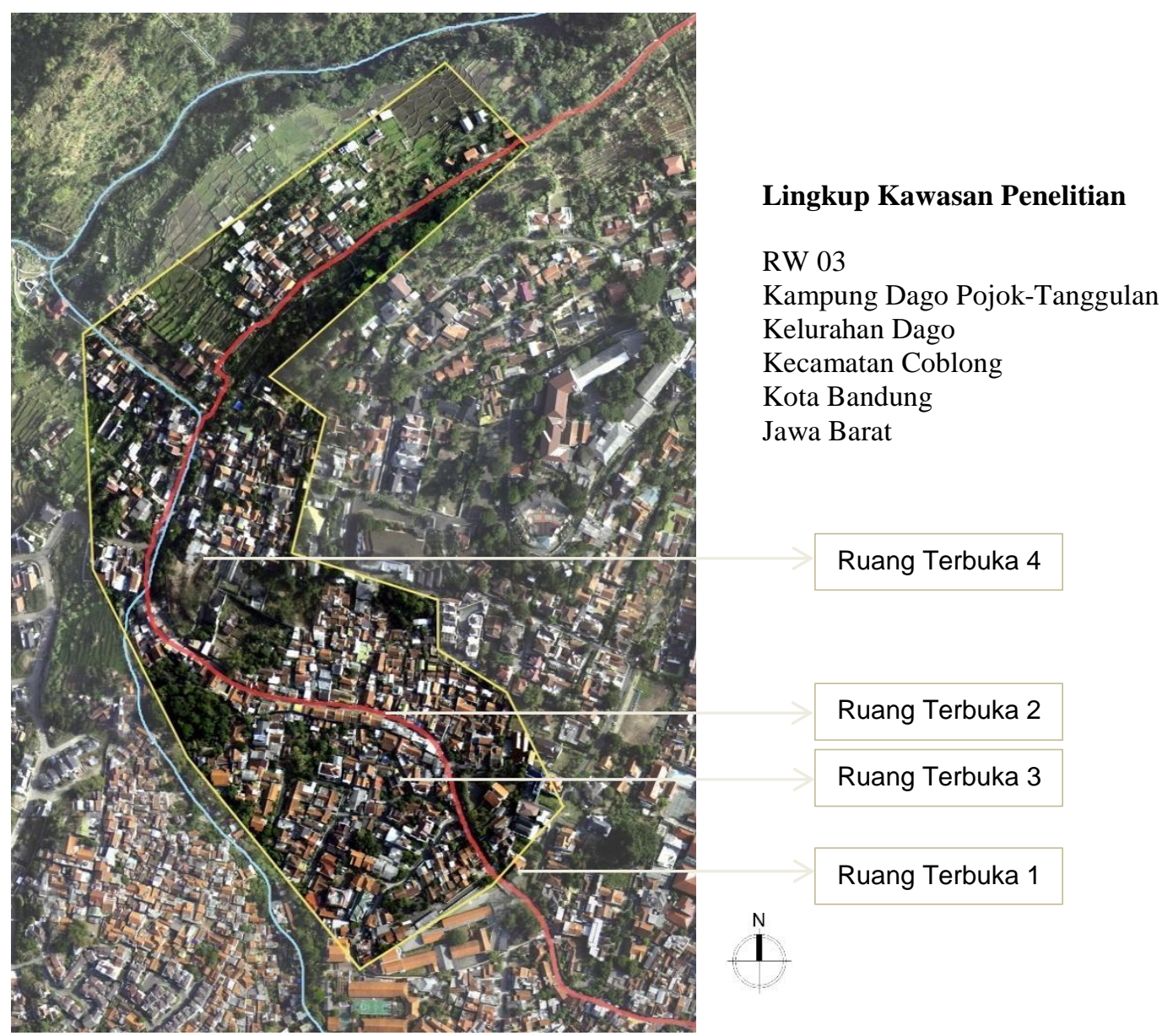

Figur 1. Empat Lokasi Ruang Terbuka yang Diamati Merepresentasikan Pengelolaan Setting Elemen Fisik Alami dan Buatan

Setelah dilakukan pendataan, maka ruang terbuka Kampung Dago Pojok dianalisis seputar perubahan setting fisik dan kaitannya dengan aktivitas sehari-hari dan insidental. Setiap area amatan dianalisis berdasarkan elemen fisik yang digunakan, seperti elemen fixed, semifixed dan non-fixed (dikaji dari teori Rapoport (1982)). Elemen-elemen tersebut dapat berubah dari waktu ke waktu sesuai dengan kebutuhan masyarakat. Kreativitas dalam menciptakan ruang akan dianalisis secara detail dengan mendeskripsikan bagaimana ruang tersebut digunakan untuk berbagai aktivitas (hubungan setting fisik dan perilaku). Aktivitas keseharian terdiri dari aktivitas dasar, ekonomi, sosial, dan hiburan ${ }^{2}$. Dan di dalamnya dapat terkandung aktivitas kreatif. Aktivitas yang berbeda diwadahi oleh elemen yang berbeda. Analisis elemen fisik pada setting fisik mengacu pada keberadaan elemen pelingkup (base plane dan vertical plane, pencahayaan, street furniture, pencapaian, dan suasana keterlingkupan). Dalam proses analisis, digunakan bebertapa teori seperti teori Jan Gehl terkait faktor pendorong interaksi sosial, Ashihara mengenai sifat ruang terbuka dalam sudut pandang arsitektur, Ching terkait bentuk dan tatanan, dan Barker mengenai behaviour setting. Dan untuk analisis setting fisik terkait elemen digunakan teori Rapoport.

\footnotetext{
2 Jan Gehl, Life Between Buildings, Van Nostrand Reinhold Company, New York, 1987, hlm. 11
} 


\section{ANALISIS}

Aktivitas bersama baik itu aktivitas sehari-hari maupun aktivitas khusus yang berkaitan dengan program kampung kreatif tidak terlepas dari ruang terbuka. Namun tidak setiap ruang terbuka digunakan untuk kegiatan kreatif karena beberapa faktor, seperti akses yang sulit, tidak adanya activity generator, atau setting fisik yang kurang mendukung.

Ruang terbuka pada kampung-kota dapat berupa lapangan, jalan atau gang, dan elemen alam seperti sawah dan sungai. Setiap setting fisik awal ruang terbuka dapat bersifat mengumpulkan aktivitas (sosiopetal) atau tidak (sosiofugal) ${ }^{3}$. Semakin banyak aktivitas masyarakat pada sebuah ruang maka akan mendorong perubahan elemen pada setting fisik (seperti elemen non-fixed, semi-fixed dan fixed). ${ }^{4}$ Ruang Terbuka yang diteliti terdiri dari empat buah ruang terbuka dengan ciri khas aktivitas dan setting yang beragam.

\subsection{HUBUNGAN SETTING FISIK DAN AKTIVITAS RUANG TERBUKA}

\subsubsection{RUANG TERBUKA 1}

Ruang Terbuka 1 merupakan area di kawasan RT 1 Kampung Dago Pojok yang diperuntukkan sebagai galeri patung permainan anak dengan memanfaatkan bentuk fisik yang memanjang. Area ini menjadi gerbang awal yang menjadi batas wilayah kampung. Adanya pihak yang mampu mengelola menjadikan area ini dapat terus berkembang.

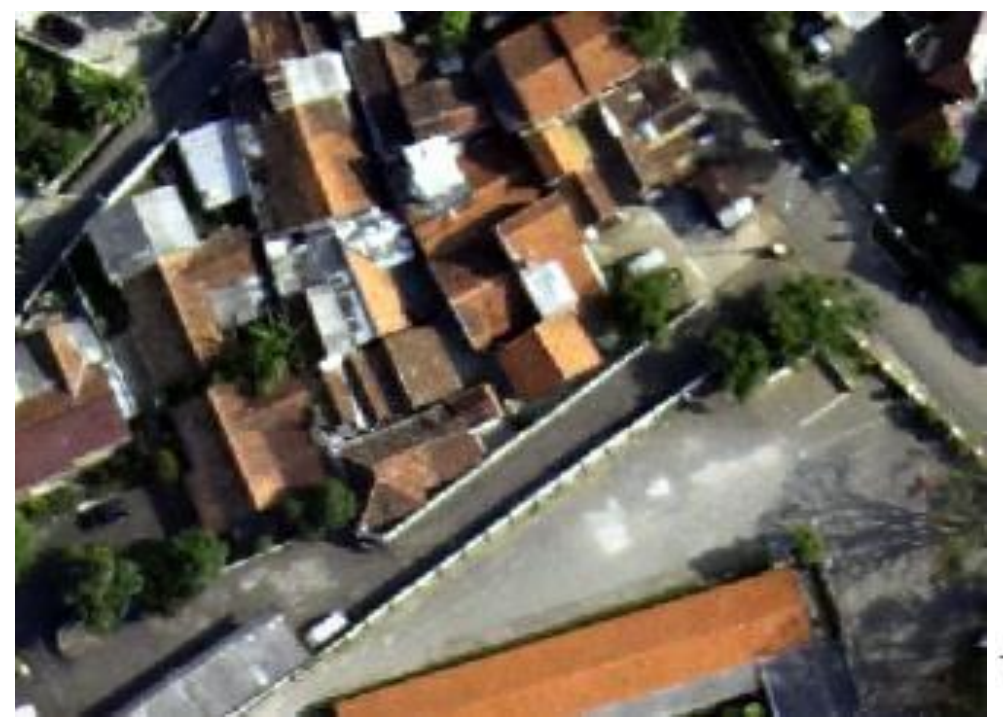

Jalan

Dago Pojok

Lapangan UNPAD

Figur 2. Lokasi Ruang Terbuka 1

Area ini terdiri dari dua titik amatan, yaitu area sirkulasi Komplek Pengairan dengan ciri khas dinding mural dan pameran patung, serta area lapangan yang dibatasi oleh urban greenery (Figur 3). Sehari-hari area sirkulasi sepanjang 40 meter ini hanya digunakan aktivitas pergerakan dikarenakan skala keterlingkupan ruang yang minim (dengan lebar jalan cukup besar dan tanpa pelingkup) menjadikan ruang ini bersifat sosiofugal. Aktivitas hiburan, sosial dan ekonomi justru ${ }^{3}$ Yoshinobu Ashihara, Exterior Design in Architecture. Van Nostrand Reinhold Company, New York, $1981^{4}$
Amos Rapoport, The Meaning of the Built Environment, SAGE Publications, Beverly Hills, 1982, hlm. 87 
banyak terjadi pada lapangan yang memiliki bentuk memusat dan memiliki elemen peneduh (pohon dan tenda) sehingga memungkinkan terjadinya aktivitas dalam jangka waktu lama. Area lapangan pun langsung berbatasan dengan permukiman dan mulut gang sehingga menjadi simpul aktivitas masyarkat sekitar. Pada pagi hari, para ibu menemani anak bermain di lapangan sambil berinteraksi satu sama lain di bawah tenda. Aktivitas yang berlangsung lama ini memancing aktivitas ekonomi seperti pedagang keliling. Sedangkan pada siang hari aktivitas dipengaruhi oleh terik matahari, sehingga subjek pengguna ruang dan aktivitas ruang pun menjadi berbeda.

Selain itu pula pada perkembangannya batas lapangan dan jalur sirkulasi berupa tembok diruntuhkan dan diganti urban greenery yang memberikan jarak pandang lebih luas, sekaligus menghubungkan kedua ruang terbuka sehingga mengaktifkan kegiatan di kedua area.

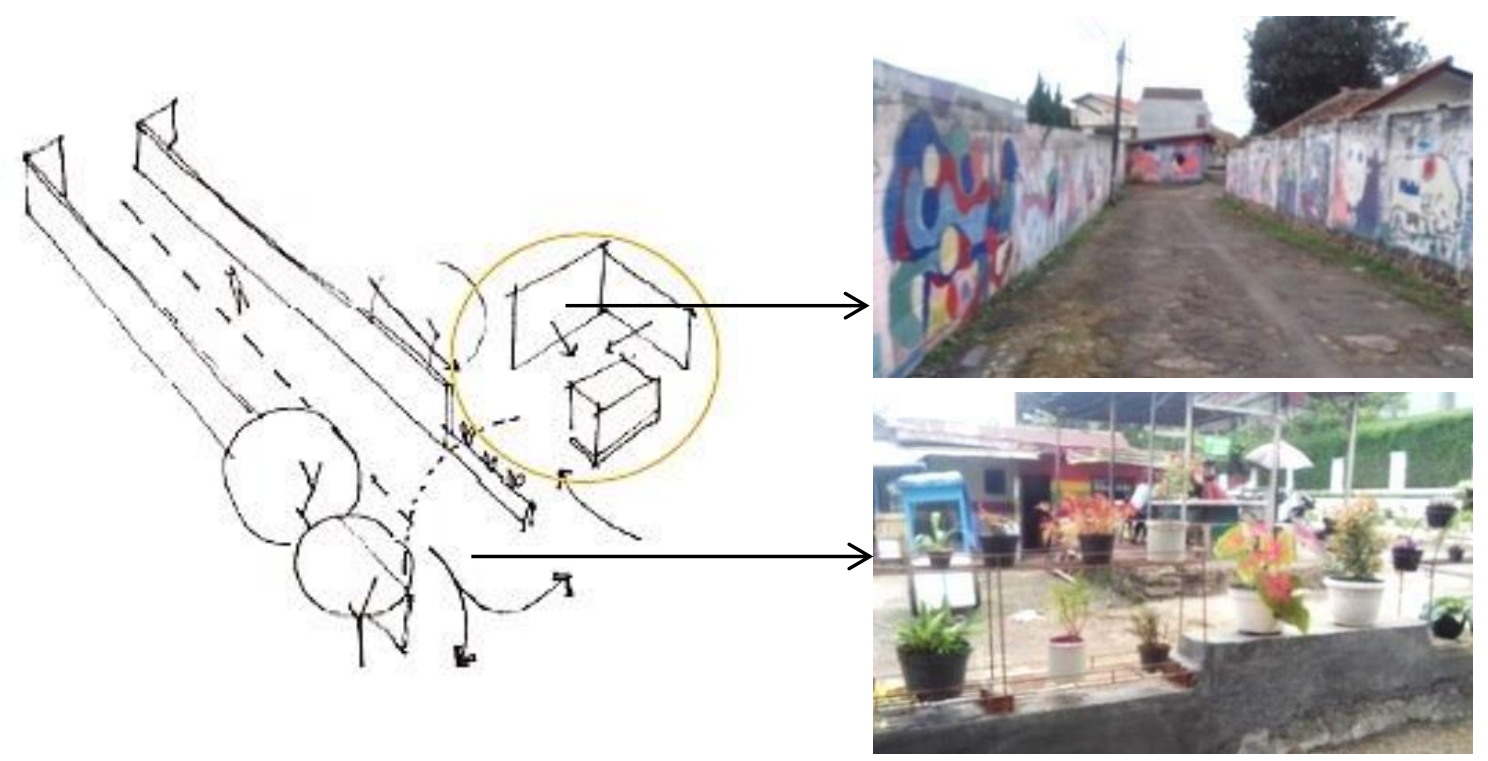

Figur 3. Ruang Terbuka 1 Terdiri dari Area Lapangan dan Sirkulasi

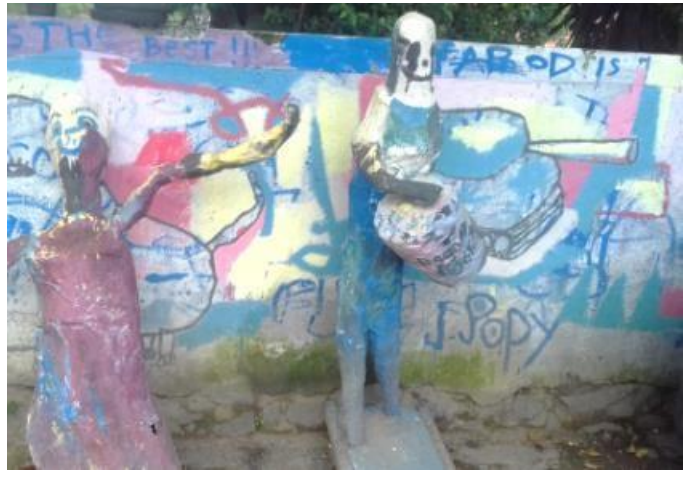

Figur 4. Galeri patung dan background dinding mural yang memberikan suasana khas sehingga mendorong aktivitas lain selain aktivitas pergerakan

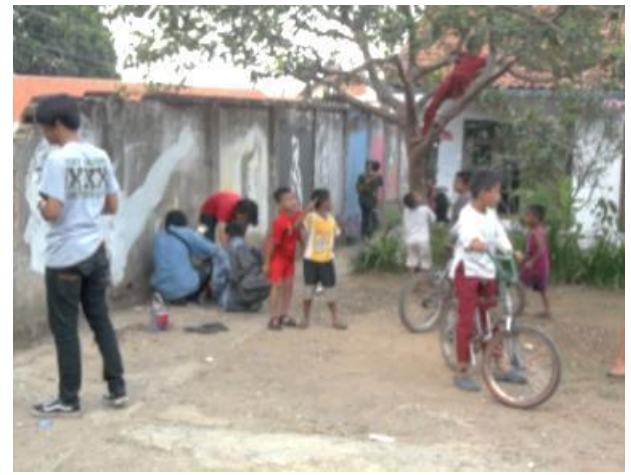

Figur 5. Lapangan menjadi daya tarik bagi aktivitas sosial, hiburan dan ekonomi masyarakat dengan kondisi yang mendukung seperti keberadaan peneduh 


\subsubsection{RUANG TERBUKA 2}

Ruang Terbuka 2 merupakan area di kawasan RT 3 Kampung Dago Pojok yang merupakan gang dan perluasan teras Komunitas Taboo. Area ini menjadi pusat kegiatan kreatif (galeri gang karya seni, tempat rapat, pembuatan karya seni, workshop, sekolah gang, pemutaran film, dsb).

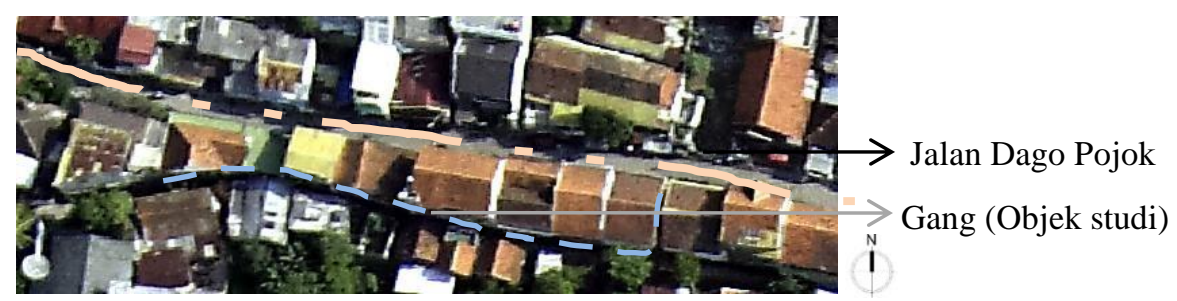

Figur 6. Lokasi Ruang Terbuka 2

Semula kawasan ini kurang terawat dengan jalur sirkulasi yang minim dan berbatasan langsung dengan saluran air yang cukup besar. Namun area ini semakin berkembang didukung dengan bentuk yang memanjang sehingga sesuai untuk dijadikan galeri gang, dekat dengan Komunitas Taboo sebagai activity generator, serta adanya perluasan teras mengakibatkan bentuknya menjadi sosiopetal. Gang ini menjadi kaya akan aktivitas sepanjang hari, baik aktivitas dasar, sosial, maupun aktivitas kreatif, juga didorong dengan keberadaan rumah di Jalan Dago Pojok yang membuka teras ke sisi gang. 

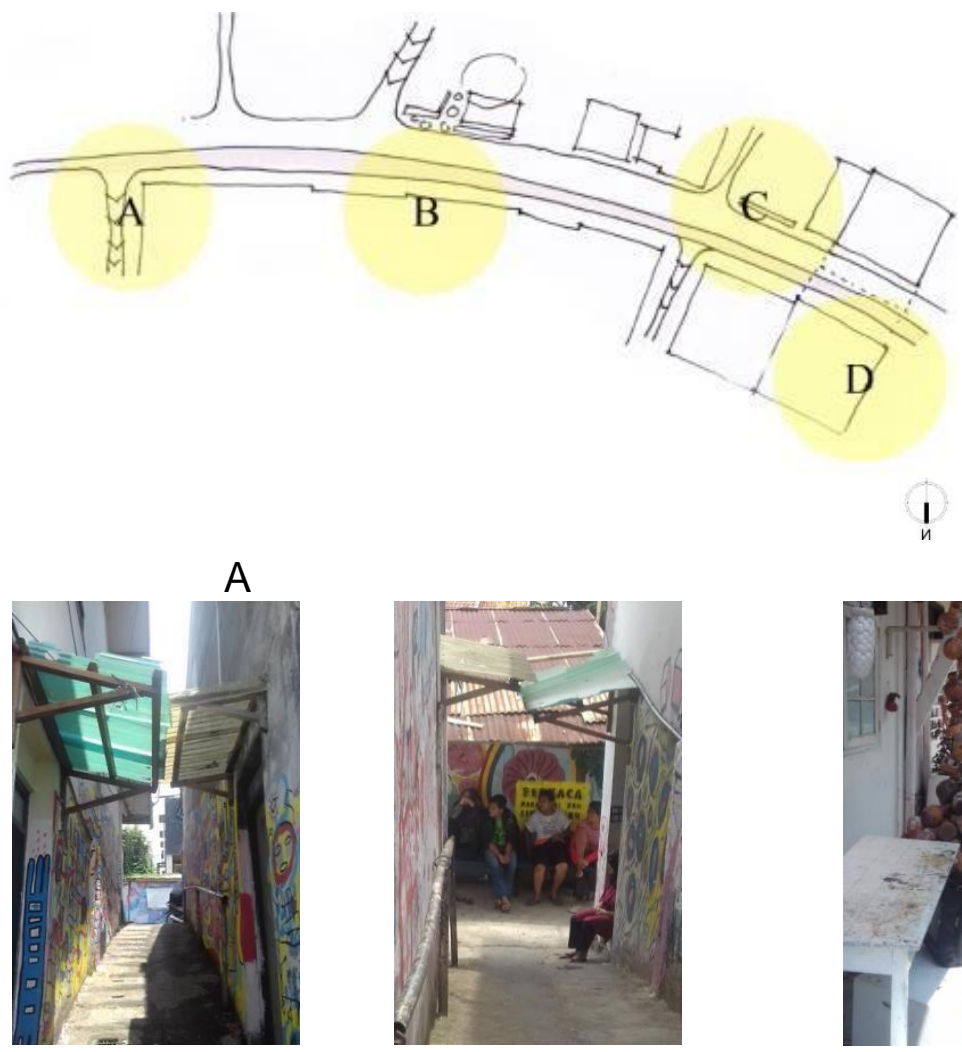

Figur 7. Masingmasing gang menjadi khas dan menarik dengan mural berwarna cerah

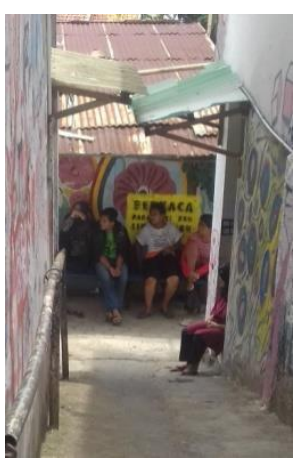

Figur 8. Simpul gang yang terlihat dari Jalan Dago Pojok

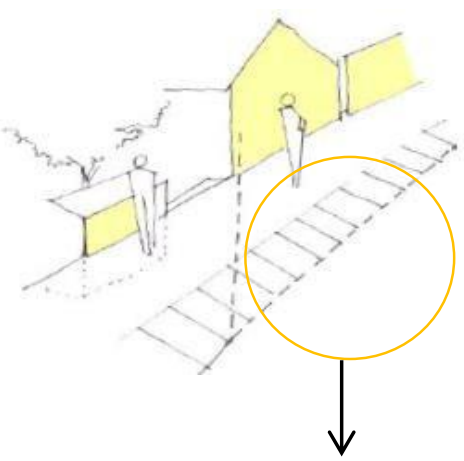

\section{B}

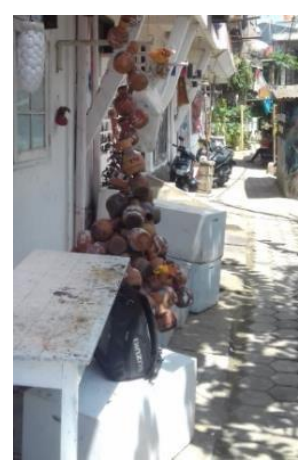

Figur 9. Teras komunitas dengan berbagai karya seni dan street furniture yang multifungsi

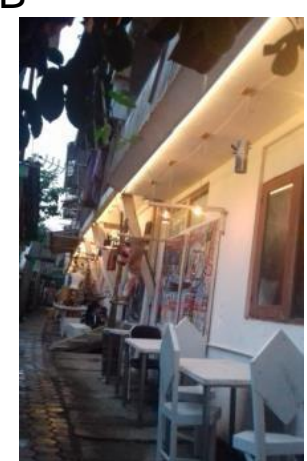

Figur 10. Kreativitas untuk menciptakan lingkungan yang estetik melalui elemen pencahayaan
C

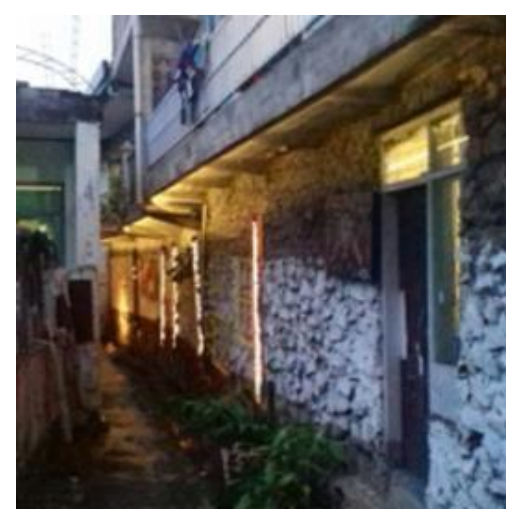

Figur 11. Sepanjang gang dengan eleman karya seni lukisan dan pencahayaan pada dinding
D

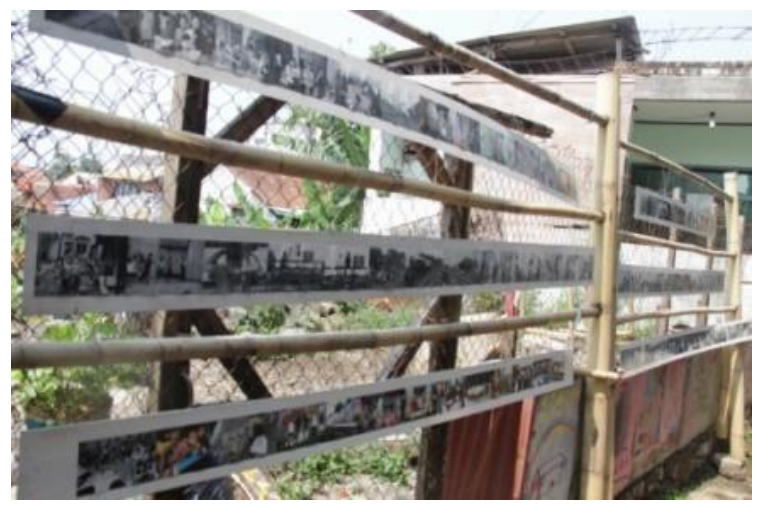

Figur 12. Galeri gang pada saat festival 
Aktivitas pada gang saling mempengaruhi satu sama lain ${ }^{4}$. Sebagai contoh, aktivitas ekonomi akibat adanya warung dan pedagang keliling mendorong interaksi sosial, demikian pula sebaliknya. Aktivitas hiburan anak juga terjadi didukung adanya karya seni yang menggali imajinasi mereka. Gang menjadi tempat dimana masyarakat nyaman melakukan aktivitas bersama. Kebutuhan ruang untuk rapat diwadahi dengan street furniture pada teras Komunitas Taboo yang fleksibel secara letak dan susunan. Area ini pun diolah agar memiliki 'ruang' pembuatan karya seni dan menyambut tamu, melalui penggunaan ruang bergantian dan melibatkan perubahan elemen setting.

\subsubsection{RUANG TERBUKA 3}

Letak Ruang Terbuka 3 bersebelahan dengan Ruang Terbuka 2, berupa lapangan dan gang yang sehari-hari digunakan sebagai wadah aktivitas sosial dan area bermain yang aman bagi anak. Pada kegiatan khusus, lapangan digunakan untuk pertunjukkan dan artshop (pameran lukisan).

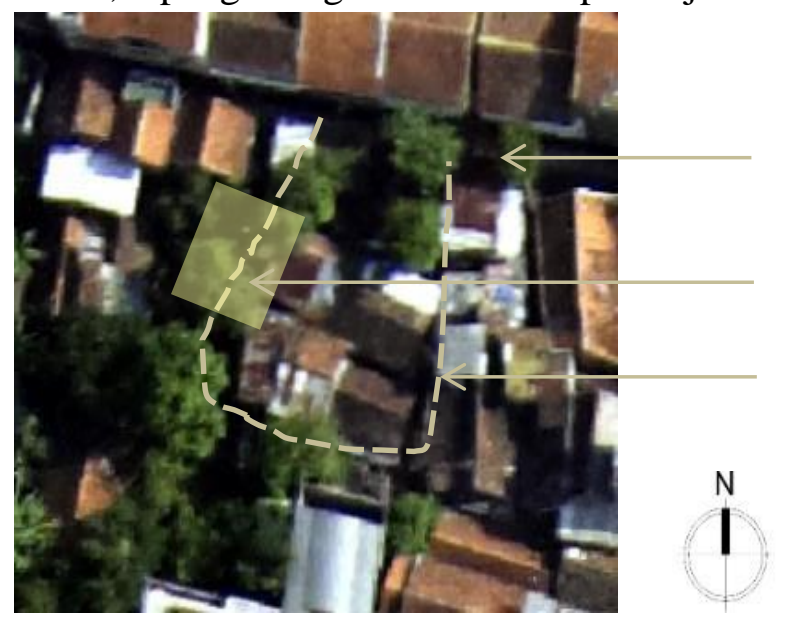

Gang

(Ruang Terbuka 2)

Lapangan

Gang (loop)

Gang

(Ruang Terbuka 2)

Lapangan

Permukiman

Akses dari

permukiman

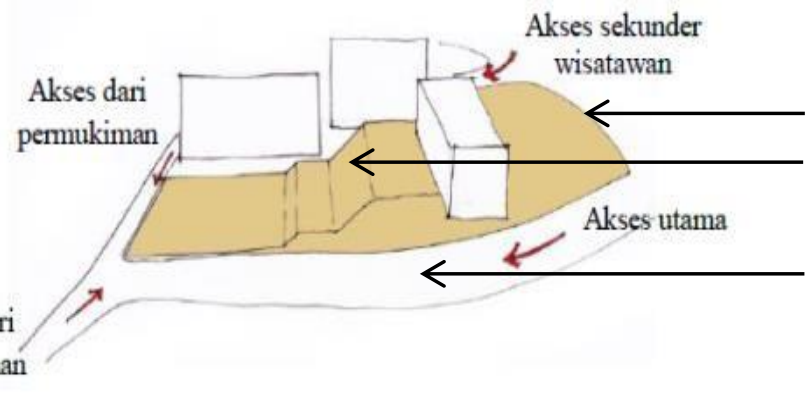

Figur 13. Kondisi Ruang Terbuka 3

Dengan bentuk yang mengelilingi lapangan, kondisi gang menjadi lebih privat dan tidak diutamakan untuk kegiatan publik. Oleh karena itu area ini dipersiapkan sebagai artshop hanya pada saat kegiatan khusus. Lain halnya dengan lapangan yang meskipun letaknya berada di kontur yang lebih rendah dari Jalan Dago Pojok namun memiliki banyak akses sehingga cocok dijadikan area pertunjukkan (Figur 13).

\footnotetext{
${ }^{4}$ Jan Gehl, op.cit. hlm. 23,25
} 

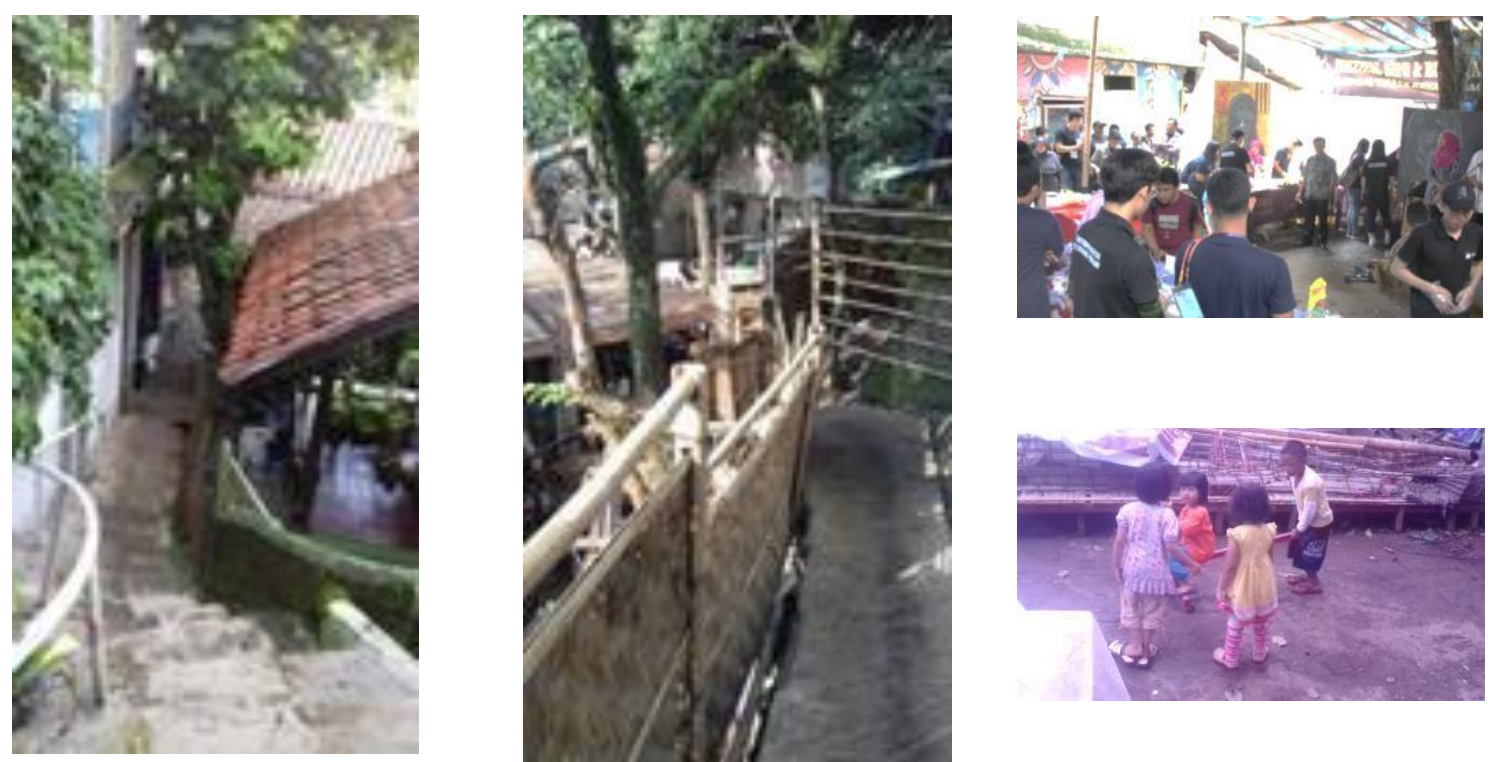

Figur 14. Sirkulasi loop digunakan Figur 15. Sirkulasi menuju Figur 16. Lapangan menjadi ruang untuk pemajangan karya lukis lapangan yang diolah dengan terbuka untuk aktivitas khusus dan railing dan dinding pemajangan

karya

hiburan anak

\subsubsection{RUANG TERBUKA 4}

Ruang Terbuka 4 memanfaatkan elemen alam sungai sebagai pusat aktivitas. Lapangan yang cukup besar dan strategis (mampu diakses langsung dari Jalan Dago Pojok dan terlihat dari jalan karena terletak pada kontur yang lebih atas (Figur 17)) menyebabkan lapangan ini berpotensi menjadi pusat pertunjukkan saat festival. Sungai sebagai pusat hiburan memancing mendorong aktivitas lain seperti aktivitas sosial dan ekonomi. 


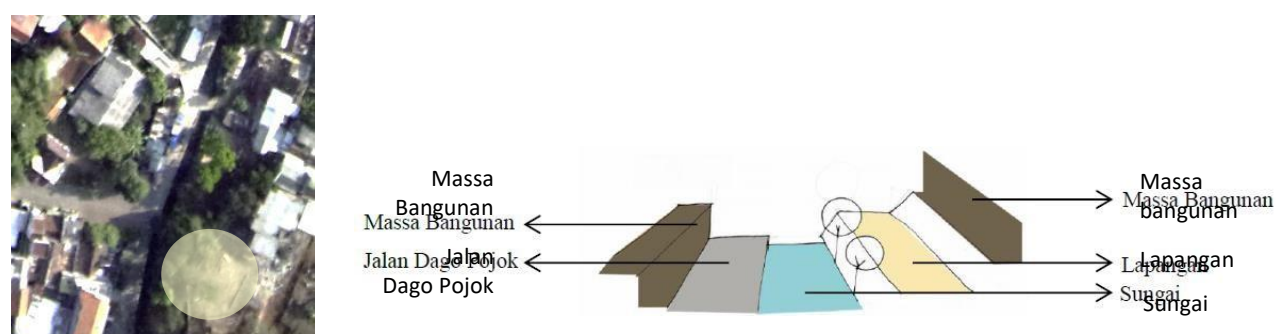

Figur 17 . Lapangan berada pada kontur yang lebih tinggi sehingga menciptakan hubungan ruang tidak langsung dengan sungai

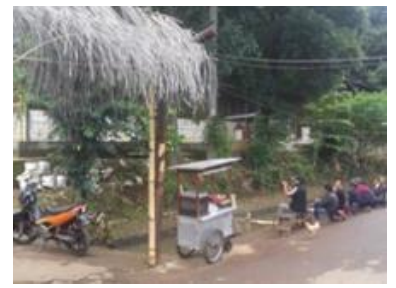

Figur 18. Sungai menjadi pusat aktivitas hiburan memancing

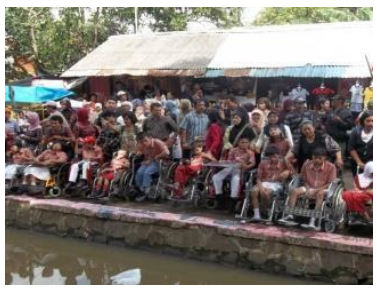

Figur 19. Kondisi samping sungai pada saat pertunjukkan

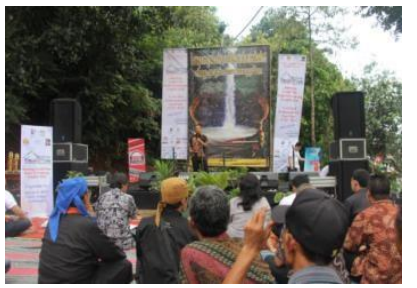

Figur 20. Pertunjukkan dengan elemen semi-fixed panggung dan tikar untuk alas duduk penonton

\subsection{PERUBAHAN SETTING FISIK}

Perubahan setting pada setiap titik memiliki sifat yang berbeda-beda. Elemen yang berubah berupa elemen non-fixed hingga elemen fixed. Perubahan dalam hal ini berupa penambahan elemen dari yang tidak ada lalu timbul gagasan untuk menciptakan elemen baru, atau berupa pergantian fungsi, tata letak dan bentuk elemen. Perubahan pada setting fisik akibat aktivitas kreatif dapat bersifat saling mendukung atau bertolak belakang dengan aktivitas dasar.

\subsubsection{PERUBAHAN PADA RUANG TERBUKA 1}

Perubahan pada aktivitas sehari-hari meliputi:

(1) Perubahan elemen non-fixed yang muncul akibat aktivitas masyarakat seperti menjemur pakaian serta aktivitas berjualan.

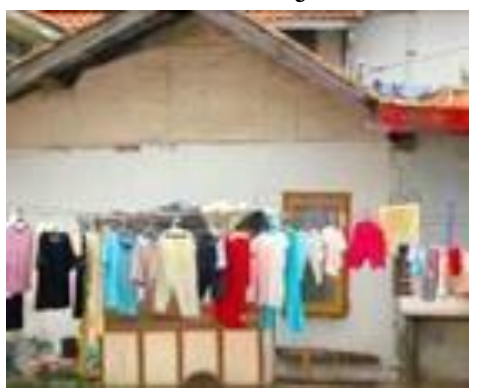

Figur 21. Jemuran pakaian membentuk vertical plane

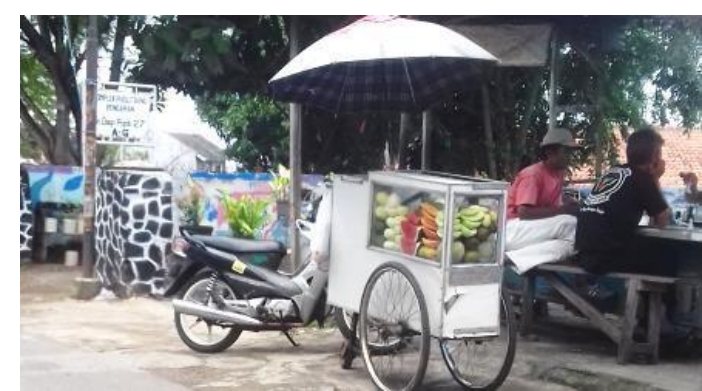

Figur 22. Pedagang keliling yang sering berkumpul di sekitar lapangan 
(2) Perubahan elemen semi-fixed terjadi pada vertical plane berupa kain pada tenda yang dipasang untuk mendukung aktivitas berjualan serta perubahan fisik terkait penggunaan lahan untuk parkir yang seringkali mengurangi intensitas aktivitas lain. Keterbatasan lahan menyebabkan masyarakat harus menggunakan ruang secara bergantian atau menciptakan solusi melalui perubahan setting fisik, seperti penggunaan elemen tenda untuk berjualan, aktivitas sosial dan panggung pertunjukkan dengan merubah kondisi vertical plane.

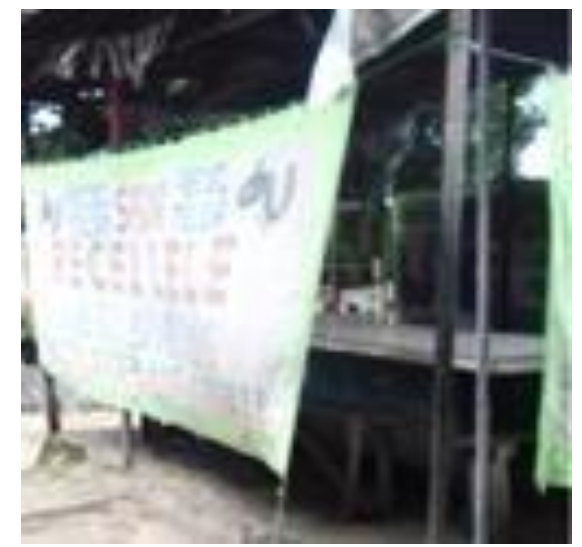

Figur 23. Tenda digunakan sebagai tempat

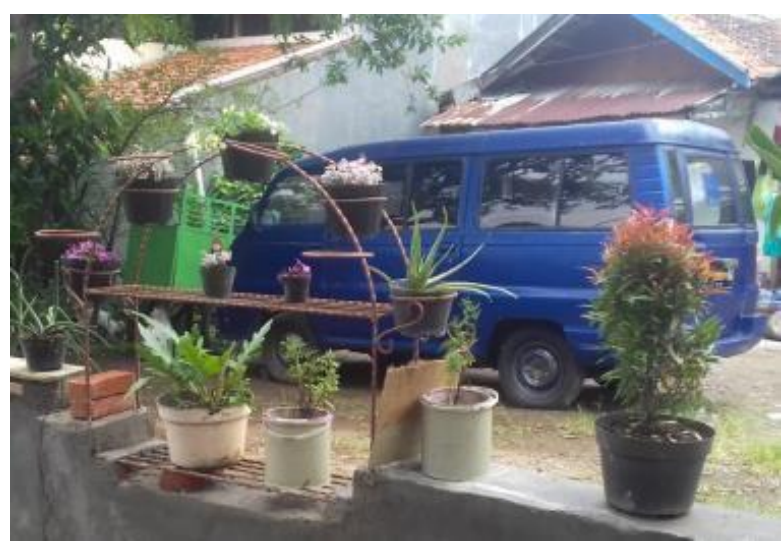

Figur 24. Lahan yang digunakan untuk parkir berjualan pada sore hari dengan menambah elemen vertikal

Perubahan pada aktivitas insidental meliputi:

(1) Perubahan elemen non-fixed pada aktivitas parade saat festival.

(2) Perubahan elemen semi-fixed terjadi pada pembentukkan panggung untuk festival dengan memberikan vertical plane pada ketiga sisi tenda yang kemudian diberi aspek estetik. Pameran patung yang mengalami perubahan jumlah, tema dan letak pada waktu tertentu merupakan contoh lain dari perubahan elemen semi-fixed. Selain itu terdapat beberapa stand yang dihias dan dilukis pada saat acara khusus.

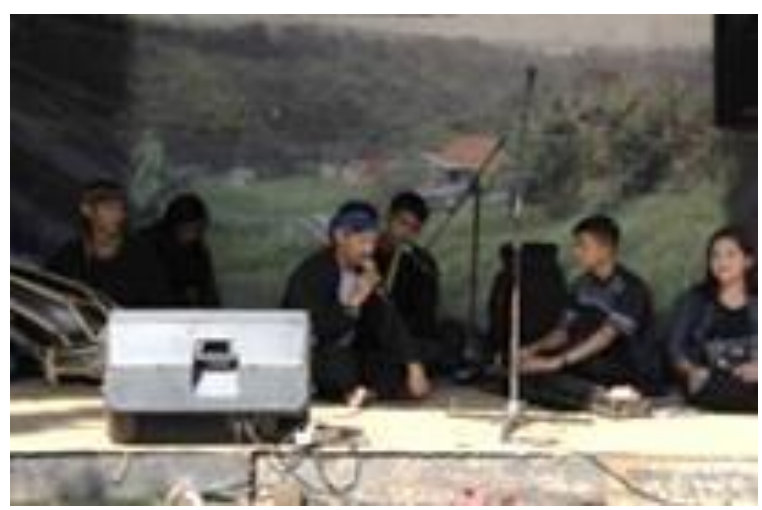

Figur 25. Penambahan dinding dekorasi background panggung sebagai pertunjukkan

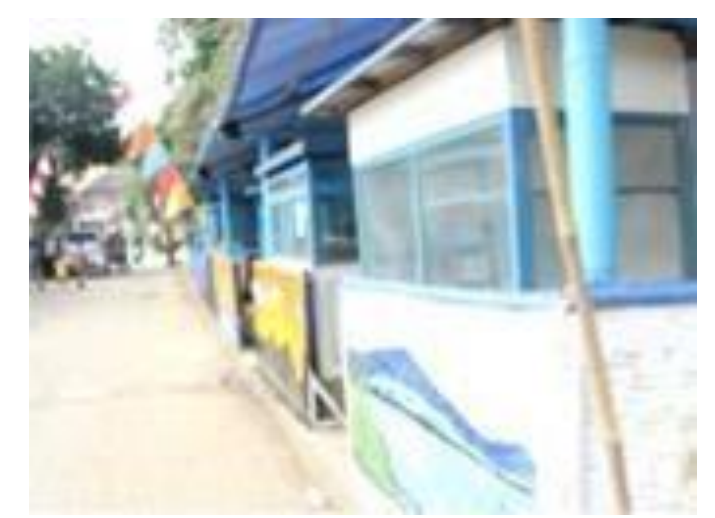

Figur 26. Stand yang dilukis pada saat acara khusus 
(3) Perubahan elemen fixed terjadi pada pengecatan dinding mural se-cara berkala untuk memberikan kesan ruang yang berbeda. Setelah dilukis mural, aktivitas pada area sirkulasi ini menjadi lebih beragam dan ruang ini dapat dimanfaatkan sebagai pembentuk citra baru kampung melalui seni melukis dinding. Selain itu terjadi perubahan lain pada elemen dinding yakni meruntuhkan dinding dan menggantinya dengan urban greenery. Pada acara khusus seperti perayaan hari kemerdekaan, tenda dapat dibongkar untuk menciptakan lahan yang lebih luas.

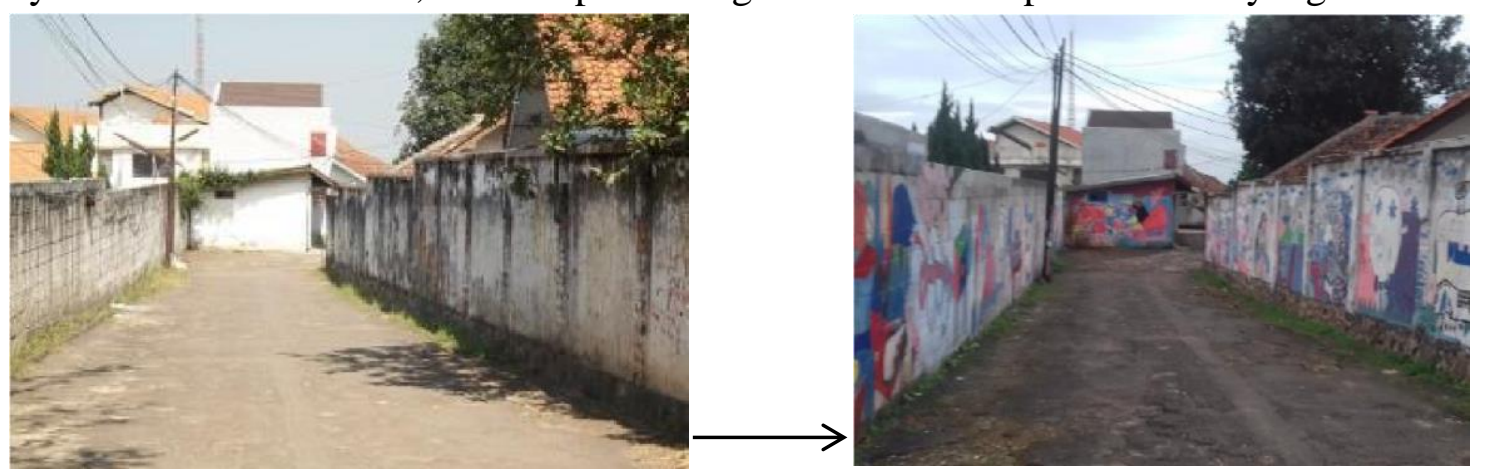

Figur 27. Mural menciptakan suasana ruang yang khas dan menarik sebagai ruang sirkulasi
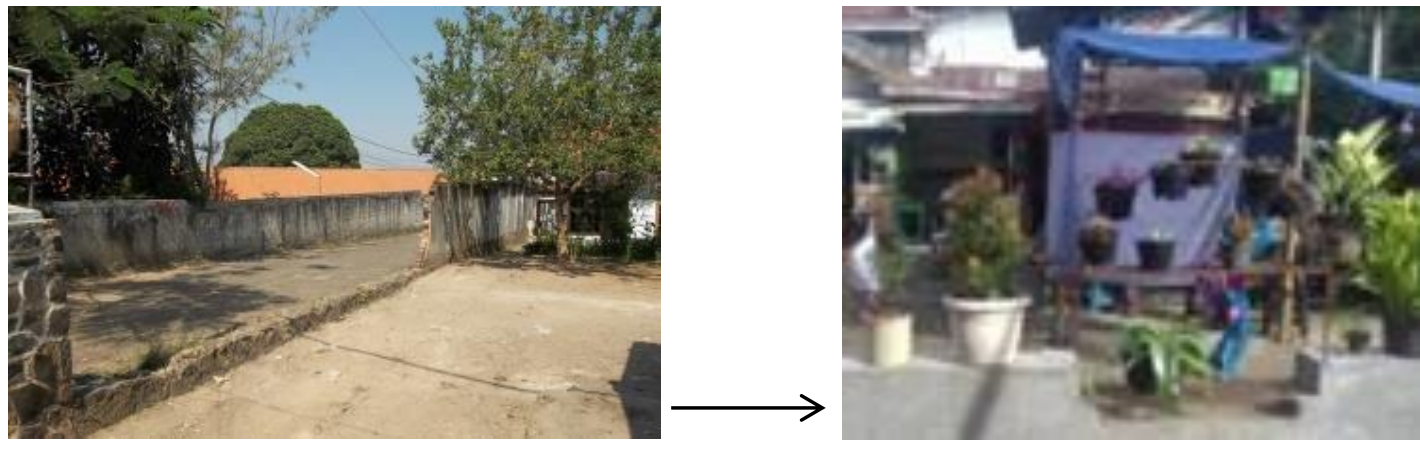

Figur 28. Dinding yang diruntuhkan dan digantikan dengan urban greenery meningkatkan kesadaran masyarakat dalam memelihara lingkungan, sekaligus mencipta keterbukaan ruang

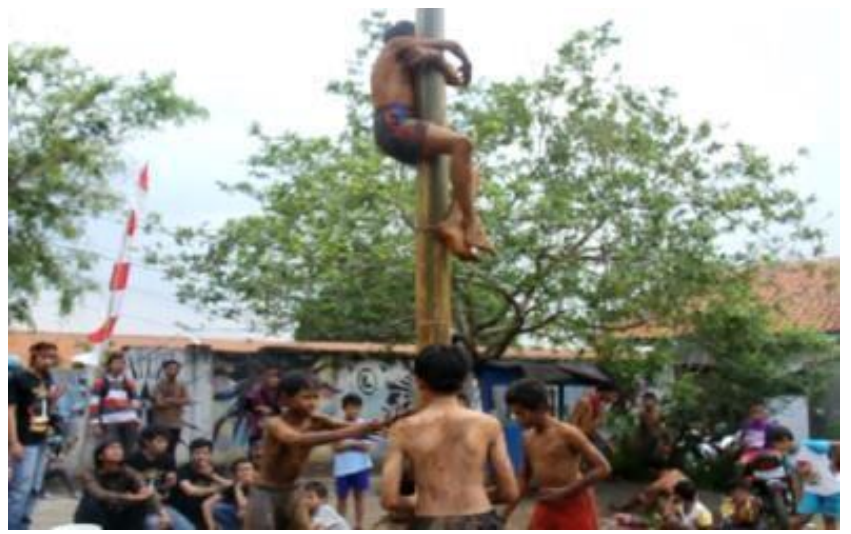

Figur 29. Keterbatasan lahan yang ada menjadikan perubahan setting fisik dapat dilakukan untuk pemenuhan sebuah aktivitas 


\subsubsection{PERUBAHAN PADA RUANG TERBUKA 2}

Kebutuhan akan ruang yang lebih besar muncul akibat aktivitas yang beragam. Hal ini memunculkan gagasan untuk menutup selokan secara semipermanen untuk menciptakan teras (pelebaran sirkulasi gang). Penutup saluran menggunakan bambu kemudian diganti dengan beton precast yang lebih kuat menahan beban aktivitas dan lebih mudah dalam perawatannya. Teras yang lebar mampu digunakan untuk berbagai kegiatan.
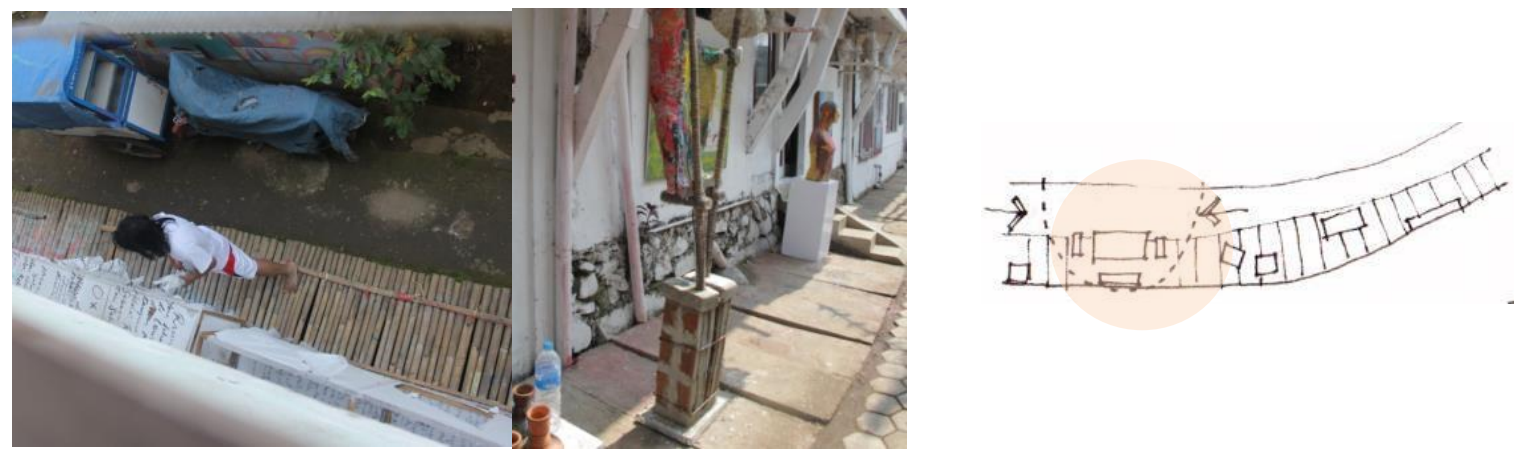

Figur 30. Perkembangan pengolahan baseplane secara kreatif

Perubahan pada aktivitas sehari-hari meliputi:

(1) Perubahan elemen non-fixed berupa kegiatan bermain anak, proses pengerjaan seni, aktivitas pedagang keliling, dan aktivitas menjemur.

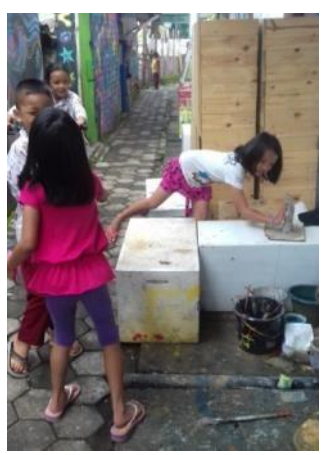

Figur 31. Ruang favorit anak karya seni sebagai media bermain

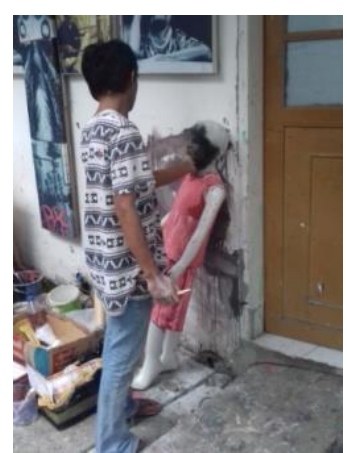

Figur 32. Teras menjadi ruang Figur 33. Jemuran pakaian pada dengan untuk berkarya dengan hasil karya vertical plane yang biasa

yang terus berkembang

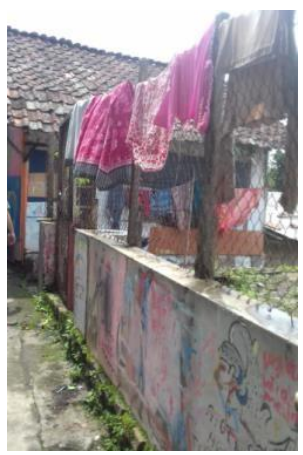

digunakan sebagai tempak pemajangan karya pada waktu festival

Perubahan elemen semi-fixed mencakup perubahan letak dan susunan furnitur yang didesain multifungsi dan hemat ruang. Selain itu, kebutuhan akan lahan parkir motor seringkali bersamaan dengan kegiatan penerimaan tamu sehingga membutuhkan toleransi masyarakat. 


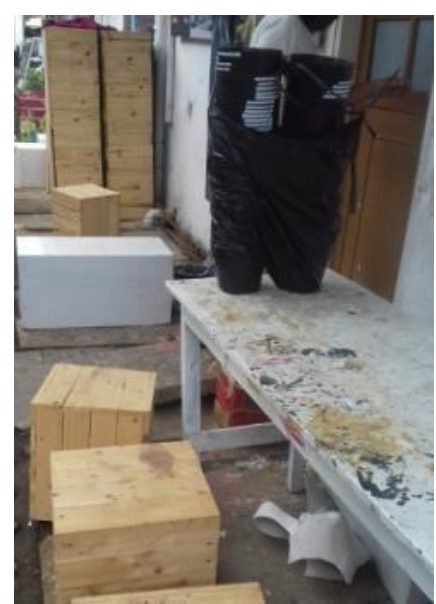

Figur 34. Boks kayu ditumpuk

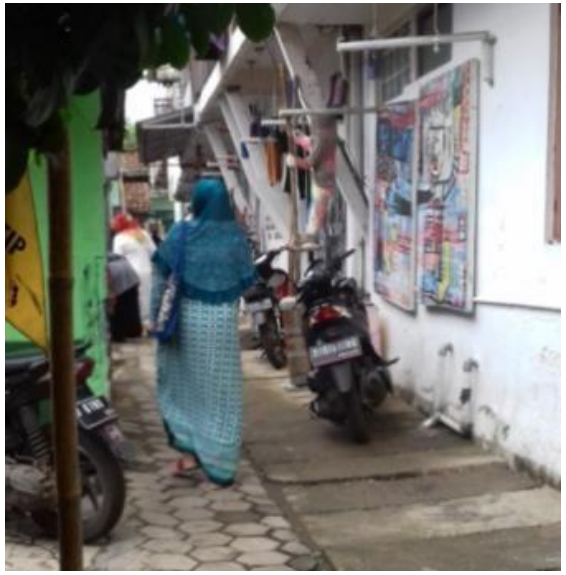

Figur 35. Pelebaran gang

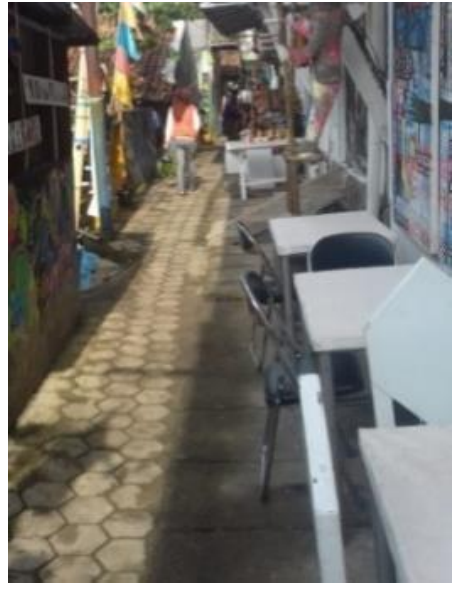

Figur 36. Ruang yang terbatas untuk menghemat ruang memungkinkan lahan parkir motor mendorong masyarakat berbagi ruang.

Beberapa karya seni 3D dengan bentuk meja dan kursi unit digunakan untuk keperluan sehari-hari.
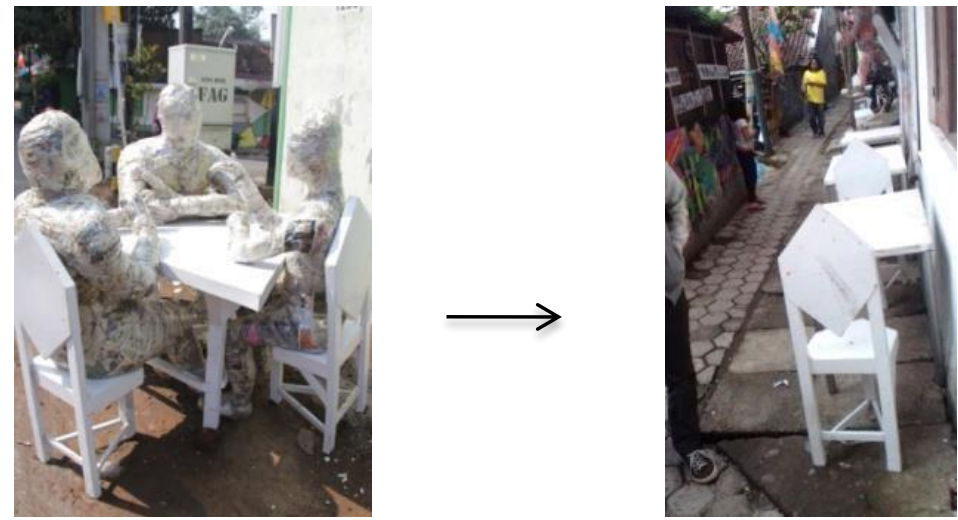

Figur 37. Karya seni 3D tentang birokrasi yang dapat digunakan sebagai furnitur

Salah satu perubahan setting yang terlihat pada malam hari adalah pencahayaan dengan kesan hangat dari elemen lampu yang sekaligus sebagai elemen seni. Kreativitas masyarakat terwujud dalam menciptakan suasana yang berbeda sehingga aktivitas malam hari menjadi lebih nyaman. 

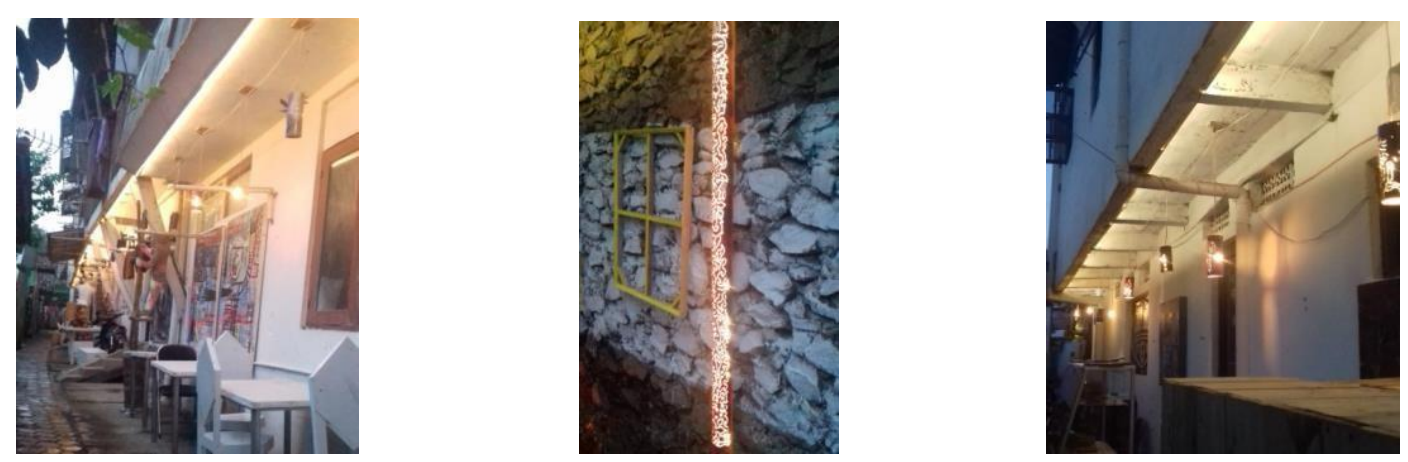

Figur 38. Suasana pada gang dengan pendaran cahaya kuning memberikan kesan berbeda dengan kondisi kampung pada siang hari.

Perubahan pada aktivitas insidental meluputi:

(1) Perubahan elemen non-fixed berupa aktivitas wisatawan yang memadati teras Komunitas Taboo.

(2) Perubahan elemen semi-fixed ditandai dengan penggunaan kotak kayu multifungsi yang sehari-hari digunakan sebagai kursi.

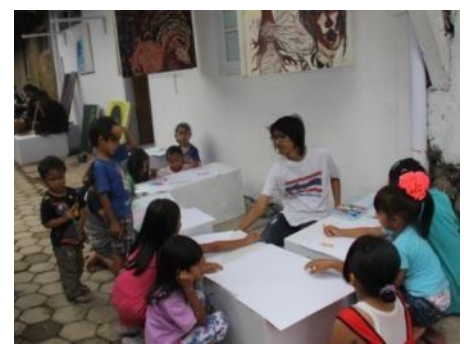

Figur 39. Boks digunakan sebagai meja pada saat sekolah

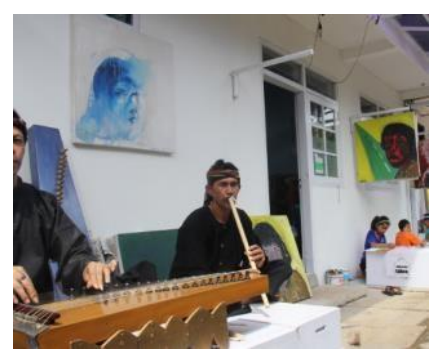

Figur 40. Boks digunakan sebagai 'panggung'

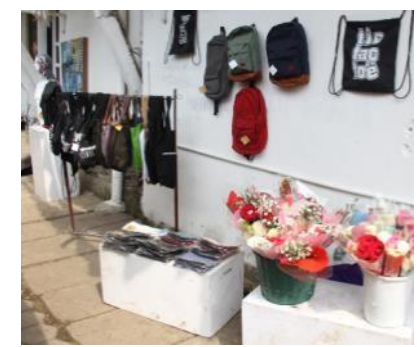

Figur 41. Boks digunakan sebagai media display karya seni

(3) Perubahan elemen fixed dilakukan pada vertical plane maupun pada base plane dengan melukis mural pada permukaan dinding dan jalan. Mural menjadikan suasana setiap ruang jalan menjadi khas dan membangkitkan semangat pemeliharaan kampung. 

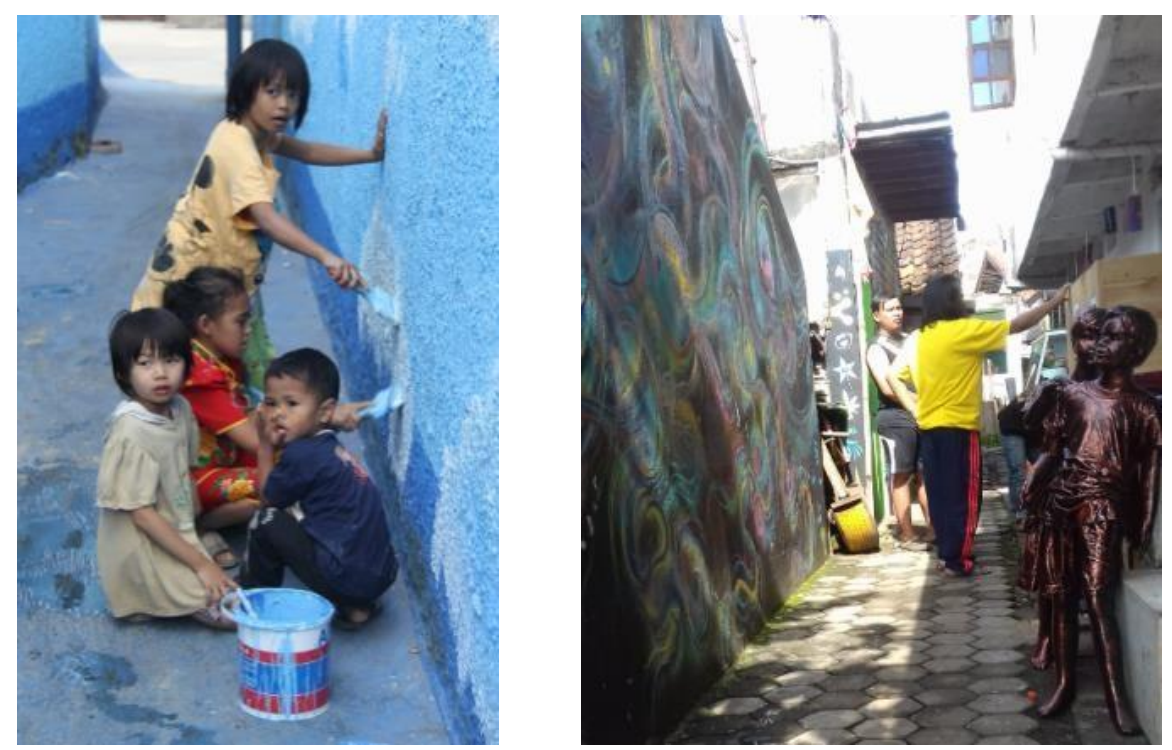

Figur 42. Mural membuka imajinasi masyarakat dan menciptakan kesan ruang yang berbeda melalui warna

\subsubsection{PERUBAHAN PADA RUANG TERBUKA 3}

Perubahan pada aktivitas sehari-hari meliputi:

(1) Perubahan elemen non-fixed berupa aktivitas menjemur dan bermain anak. Aktivitas menjemur dilakukan di atap rumah atau dengan menambah vertical plane. Aktivitas bermain anak di teras, gang dan lapangan dapat menggunakan sepeda atau gerobak.

(2) Perubahan elemen semi-fixed dilakukan dengan menambah atap terpal di lapangan sebagai perlindungan terhadap cuaca dalam jangka waktu lama. Apabila tidak digunakan untuk keperluan khusus, terpal akan dilepas dan lapangan mengandalkan vegetasi sebagai pelingkup atap.

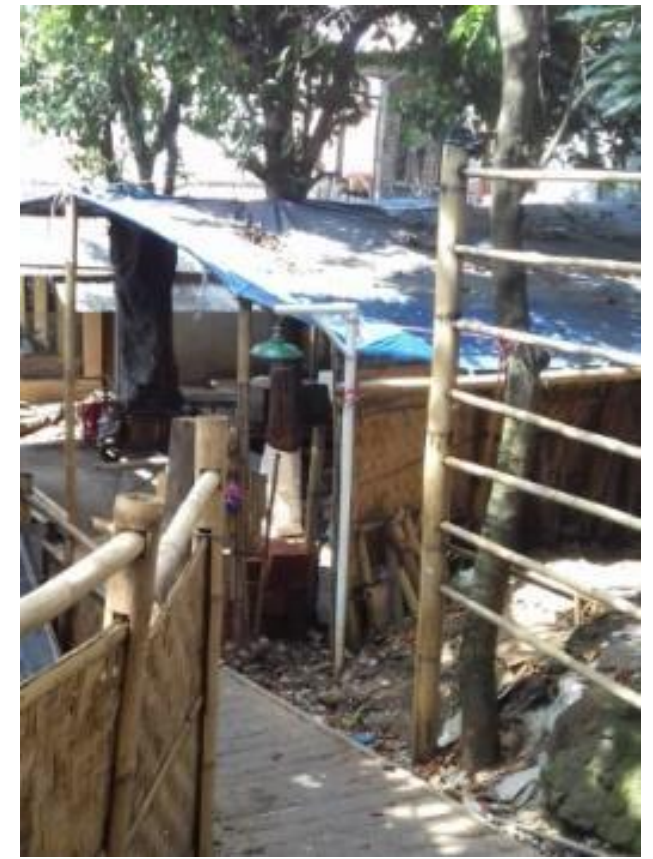

Figur 43. Atap dipasang pada saat lapangan digunakan untuk penyimpanan material pembangunan 
Perubahan pada aktivitas insidental meliputi:

(1) Perubahan elemen non-fixed berupa pameran lukisan (artshop di sepanjang gang) yang hanya dipasang saat festival. Sehari-hari lingkungan Ruang Terbuka 3 menjadi privat dengan gang berperan sebagai perluasan teras.

(2) Perubahan elemen semi-fixed berupa penambahan atap sebagai pelingkup pada acara pemutaran film atau festival di lapangan, serta pemasangan panggung dan alas untuk duduk pada saat pertunjukkan. Penambahan elemen non permanen ini dibutuhkan karena lapangan bersifat multifungsi dengan kebutuhan tataan yang berbeda, serta pengolahan secara permenan tidak memungkinkan akibat status lahan milik perseorangan (bukan milik publik). Penambahan vertical plane sebagai sekat dimanfaatkan sebagai karya seni. Sekat berfungsi membatasi area lapangan yang digunakan publik dengan rumah warga.

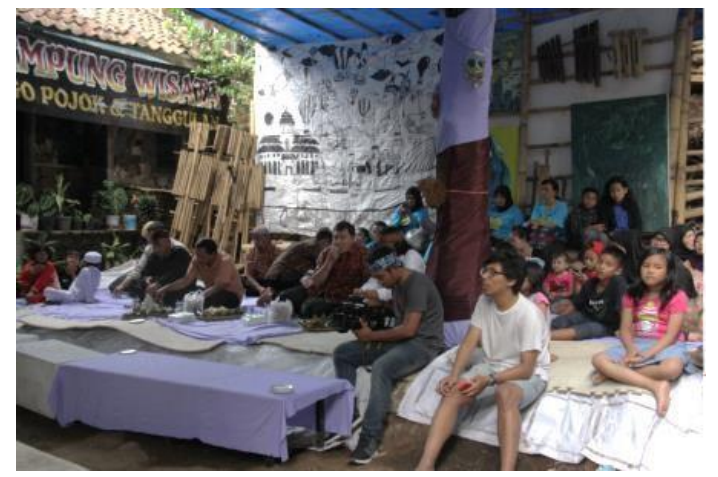

Figur 44. Dinding sekat sebagai pelingkup sekaligus sebagai karya seni

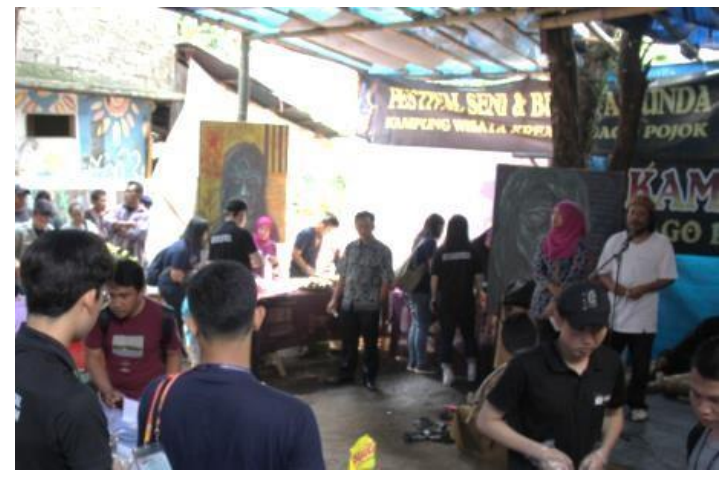

Figur 45. Atap terpal sebagai pelindung kegiatan di lapangan dari cuaca

\subsubsection{PERUBAHAN RUANG TERBUKA 4}

Perubahan mayor pada area ini adalah peningkatan elevasi base plane dan pemasangan fasilitas bermain secara permanen di lapangan yang menghambat aktivitas lain (festival dan pertunjukkan). Demikian pula pemasangan pagar menghambat kegiatan festival yang semula dapat ditonton dari luar lapang.

Perubahan pada aktivitas sehari-hari meliputi:

(1) Perubahan elemen non-fixed berupa kegiatan anak dengan meng-gunakan sepeda dan gerobak, pedagang keliling, aktivitas hiburan memancing dan aktivitas ojek.

(2) Perubahan elemen semi-fixed berupa parkir mobil dan motor sepanjang jalan, serta bangku untuk keperluan memancing. Bangku pendek hanya digunakan saat terdapat kegiatan memancing. Beberapa pemancing membawa bangku mereka sendiri. 

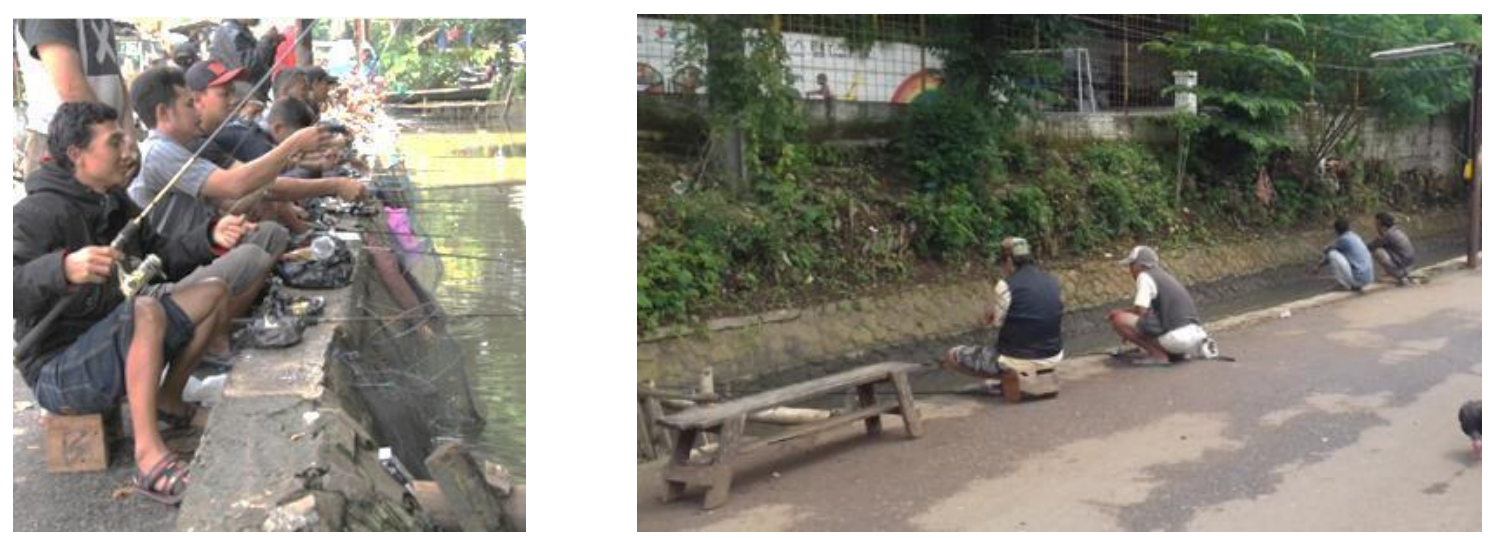

Figur 46. Aktivitas memancing memunculkan kebutuhan akan kursi yang sifatnya fleksibel baik letak maupun jumlah

(3) Perubahan elemen fixed terjadi pada pemindahan atau penambahan lampu jalan yang muncul karena adanya kebutuhan masyarakat akan penerangan ke arah sungai. Selain itu terdapat elemen mural di dinding lapangan yang menjadi daya tarik khususnya bagi anak.

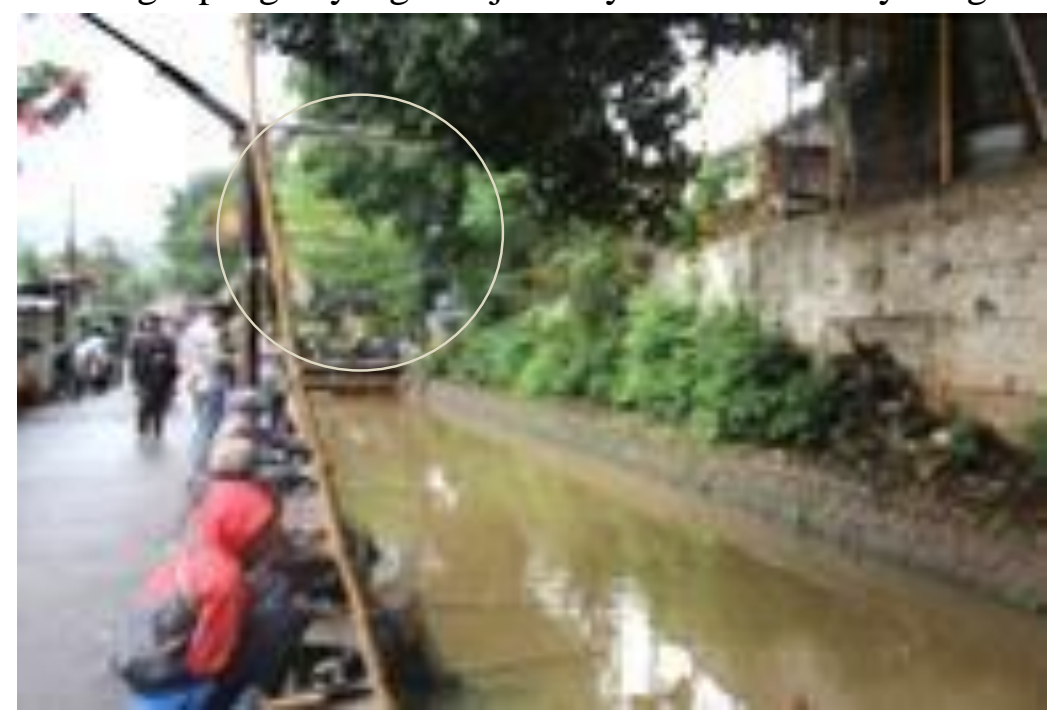

Figur 47. Semula lampu mengarah ke jalan, namun untuk menerangi aktivitas memancing pada malam hari, maka lampu dipasang ke arah sungai.

Perubahan pada kegiatan insidental meliputi:

(1) Perubahan elemen non-fixed berupa aktivitas wisatawan dan masyarakat yang menghadiri festival.

(2) Perubahan elemen semi-fixed terjadi di lapangan pada tenda yang dipasang untuk panggung dan tikar yang digelar untuk memberi kenyamanan bagi penonton sekaligus memperjelas batas ruang duduk penonton. Selain itu, perubahan juga terdapat pada setting ruang jalan dengan didirikannya stand makanan dari meja atau stand bambu yang didekor secara kreatif yang membentuk vertical plane sepanjang pinggir sungai. 


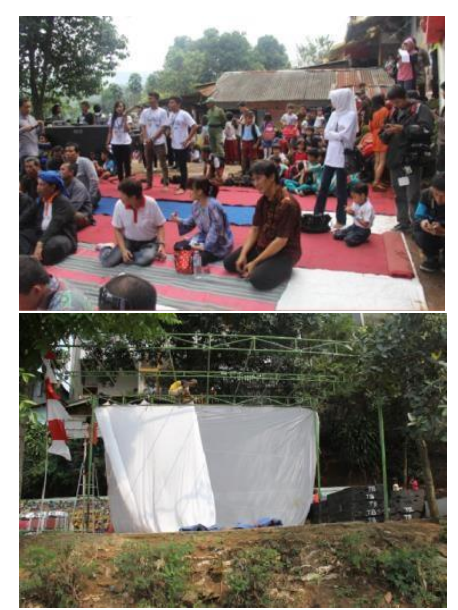

Figur 48. Base plane dan over head yang diolah non permanen memungkinkan lapangan kebutuhan

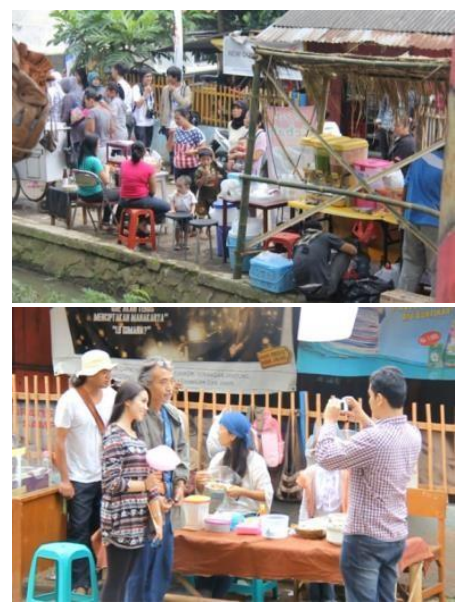

Figur 49. Pada tepi sungai terdapat aktivitas ekonomi secara yang diolah secara kreatif digunakan untuk berbagai

Setelah mengetahui perubahan yang dilakukan pada keempat titik, diketahui bahwa aktivitas mendorong terjadinya perubahan setting fisik. Beberapa aktivitas muncul karena adanya setting fisik yang mendukung. Perkembangan aktivitas yang semakin beragam menuntut setting fisik yang beragam pula. Keterbatasan lahan memunculkan kreativitas masyarakat dalam menciptakan perubahan setting fisik. Perlu diketahui perbandingan kondisi pada setiap titik, bagaimana aktivitas yang sama dapat menghasilkan perbedaan perubahan setting fisik dan bagaimana perbedaan itu terjadi.

Tabel 1 Perbandingan Perubahan Setting Fisik Pada Titik Ruang Terbuka

\begin{tabular}{|c|c|c|c|c|c|c|c|c|c|c|c|c|c|}
\hline & \multicolumn{7}{|c|}{ AKTIVITAS SEHARI-HARI } & \multicolumn{6}{|c|}{ AKTIVITAS KHUSUS } \\
\hline TITIK & AENJEMUR & EKONOMI & SOSIAL & $\begin{array}{l}\text { PENBUATAN } \\
\text { KARYA }\end{array}$ & $\begin{array}{c}\begin{array}{c}\text { BERUAIN } \\
\text { ANAK }\end{array} \\
\end{array}$ & $\begin{array}{c}\text { PEMBAANGUN- } \\
\text { AN }\end{array}$ & MEMANCING & MURAL & 2D & 3D & $\begin{array}{c}\text { URBAN } \\
\text { FARM } \\
\end{array}$ & \begin{tabular}{|c|}
$\begin{array}{c}\text { PERTUNJUK- } \\
\text { KAN }\end{array}$ \\
\end{tabular} & EKONOMII \\
\hline 1 & $\mathrm{~N}$ & $\mathrm{~N}, \mathrm{~S}(\mathrm{VP})$ & 0 & - & 0 & - & - & $\mathrm{N}, \mathrm{F}$ & - & $\mathrm{s}$ & $\mathrm{F}$ & $\mathrm{S}(\mathrm{VP})$ & $\mathrm{s}$ \\
\hline 2 & $\mathrm{~N}$ & $\mathrm{~N}, \mathrm{~S}$ & $\mathrm{~S}(\mathrm{FU})$ & $\mathrm{N}$ & 0 & - & - & $\mathrm{N}, \mathrm{F}$ & $\mathrm{s}$ & s & $\mathrm{F}$ & - & - \\
\hline 3 & $\mathrm{~N}$ & - & 0 & - & $\mathrm{N}$ & $\mathrm{S}(\mathrm{OH})$ & - & - & $\mathrm{s}$ & - & - & $\mathrm{S}(\mathrm{OH}, \mathrm{BP}, \mathrm{VP})$ & $\mathrm{s}$ \\
\hline 4 & & $\mathrm{~N}$ & 0 & - & $\mathrm{N}$ & - & $\mathrm{s}$ & $\mathrm{N}, \mathrm{F}$ & & - & - & $\mathrm{S}(\mathrm{OH}, \mathrm{BP})$ & $\mathrm{N}, \mathrm{S}$ \\
\hline & & & & & & & & & & & & & \\
\hline
\end{tabular}

Aktivitas ekonomi pada titik Ruang Terbuka 1 dan 2 menghasilkan perubahan setting fisik semi permanen yakni dengan penambahan meja dan kursi serta penambahan vertical plane pada tenda, di samping aktivitas pedagang keliling. Sedangkan aktivitas ekonomi pada titik 4 didominasi aktivitas pedagang keliling karena merupakan simpul dari beberapa akses utama kampung (Kampung Tanggulan, perumahan, Kampung Cikalapa, dsb). Adapun pada titik 3 tidak terdapat aktivitas sehari-hari ekonomi karena merupakan area permukiman yang lebih privat dan berada pada kontur bawah, sehingga tidak dilalui pedagang keliling.

Aktivitas sosial terjadi pada seluruh titik pengamatan, namun pada titik 2lah terjadi perubahan setting fisik dikarenakan ada perubahan penggunaan furnitur yang dinamis, baik dari segi letak dan pemanfaatan. Pada titik ini terdapat berbagai macam pusat kegiatan, sehingga 
aktivitas membutuhkan ruang yang lebih fleksibel. Sedangkan pada titik lain aktivitas sosial terjadi tidak dalam waktu lama sehingga tidak membutuhkan perubahan bentuk, jumlah dan letak setting (penggunaan berbagai pihak pada sebuah ruang dilakukan bergantian).

Aktivitas bermain anak yang menggunakan alat permainan (sepeda, gerobak, dsb) terjadi pada ruang terbuka dengan luas yang memungkinkan, seperti pada lapangan. Pada ruang terbuka dengan bentuk linear (gang) ruang gerak permainan anak menjadi terbatas. Ruang Terbuka 3 dan 4 memiliki lapangan yang cukup luas dengan banyak akses dari permukiman sehingga pada aktivitas sehari-hari banyak didatangi anak-anak. Ruang Terbuka 1 memiliki lapangan yang tidak terlalu luas dengan kondisi yang kurang nyaman, sehingga minim aktivitas anak dalam jangka waktu lama. Pada Ruang Terbuka 2, aktivitas anak dengan pergerakan luas berlangsung hanya pada kondisi tertentu di saat Ruang Terbuka 3 sedang tidak dapat digunakan karena kepentingan lain (misalnya pembangunan).

Sedangkan untuk aktivitas dan setting fisik khusus seperti mural, pembuatan dan pameran karya seni 2D, 3D, kegiatan pertunjukkan dipengaruhi oleh adanya setting fisik yang mendukung dan mampu menyediakan ruang bagi aktivitas kreatif. Contohnya wilayah tempat tinggal inisiator, activity generator (ketua RT, ketua paguyuban, seniman) menyebabkan sebuah wilayah tersentuh aspek kreatif. Contoh lain, ruang yang memungkinkan untuk kegiatan publik dari segi fisik (memiliki akses yang baik dan luas) berpotensi dijadikan ruang pertunjukkan yang kemudian karena adanya aktivitas maka perubahan setting fisik pun dilakukan.

\section{KESIMPULAN}

Kampung-kota tidak terlepas hari fenomena keterbatasan lahan dimana permukiman urban terus bertumbuh. Kampung kreatif hadir dengan kekhasan dalam mengelola ruang yang ada menjadi lebih bermakna melalui aspek seni budaya yang diaplikasikan dalam setting fisik. Keterbatasan ruang tidak menghambat kreativitas masyarakat dalam menciptakan ruang yang memenuhi kebutuhan akan aktivitas mereka yang beragam, dari aktivitas sehari-hari hingga aktivitas insidental. Oleh sebab itulah muncul perubahan setting fisik yang diciptakan masyarakat sebagai solusi pemenuhan kebutuhan ruang.

Beberapa aktivitas muncul dipengaruhi oleh setting awal. Setting fisik mempengaruhi intensitas dan ketertarikan aktivitas masyarakat. Setelah aktivitas tersebut ada dan kemudian berkembang, maka dibutuhkan upaya perubahan setting fisik, baik dari segi bentuk, fungsi, ukuran, dan tata letak. Namun, beberapa setting fisik murni muncul dari gagasan masyarakat.

Perubahan setting fisik pada setiap titik memiliki ciri yang berbeda, dipengaruhi oleh aktivitas yang berbeda, keberadaan pengelola dan ruang yang mendukung. Aktivitas yang sama pada keempat titik belum tentu menghasilkan perubahan yang sama. Bahkan aktivitas yang sama bisa saja menghasilkan perubahan setting fisik maupun tidak. Perubahan setting fisik menandakan adanya kreativitas masyarakat dalam mengolah lingkungannya.

\section{Adapun perubahan dapat dikategorikan sebagai berikut.}

(1) Perubahan pada elemen non-fixed yakni seputar aktivitas masyarakat, dimana aktivitas dasar, hiburan, sosial dan ekonomi saling mempengaruhi. Sebagai contoh aktivitas ekonomi pedagang keliling dapat memunculkan aktivitas sosial pada gang Ruang Terbuka 2. Atau aktivitas sosial pada tenda Ruang Terbuka 1 dapat memunculkan aktivitas ekonomi dengan datangnya pedagang keliling. Aktivitas bermain anak dapat meningkatkan interaksi sosial para ibu. Bahkan 
aktivitas kreatif yang sifatnya insidental dapat memicu lebih banyak aktivitas lain, seperti aktivitas ekonomi dilakukan oleh banyak masyarakat kampung di sepanjang jalan. Adanya festival memancing Ruang Terbuka 4 akan mendatangkan banyak orang yang menonton, berjualan, dan bersosialisasi.

(2) Perubahan pada elemen semi-fixed yang banyak terjadi adalah seputar perabot jalan yang meningkatkan intensitas aktivitas komunal masyarakat dan perabot multifungsi untuk menghemat ruang, seperti pada Ruang Terbuka 2. Selain itu, pelingkup berupa atap atau dinding non permanen pun diupayakan karena pengelolaan secara permanen tidak dimungkinkan akibat terbatasnya lahan. Perubahan setting berupa atap dan dinding non permanen terjadi pada tenda Ruang Terbuka 1, lapangan Ruang Terbuka 3 pada saat festival dan ketika digunakan sebagai lahan penyimpanan material pembangunan, dan lapangan Ruang Terbuka 4 pada saat festival. Patung dan karya seni 2D juga menjadi elemen semi-fixed yang mengalami perubahan baik bentuk maupun letaknya.

(3) Perubahan pada elemen fixed terjadi seputar pengadaan elemen mural yang mengubah wajah kampung pada Ruang Terbuka 1,2, dan 4, upaya urban greenery, pengolahan base plane pada ramp dan saluran air, dsb.

Perubahan terkait setting fisik paling banyak dan sering terjadi pada Ruang Terbuka 2 yang merupakan pusat kegiatan kreatif. Komunitas Taboo dengan Bapak Rahmat Jabaril sebagai inisiator kampung kreatif Dago Pojok memungkinkan banyak perubahan lingkungan, salah satunya terkait produksi karya seni. Selain itu, banyaknya kegiatan tamu dan wisatawan yang disambut oleh Bapak Rahmat Jabaril menyebabkan ruang harus fleksibel untuk banyak orang, berbagai jenis acara dan waktu pelaksanaan acara. Lain halnya dengan titik kreatif lain yang seringkali pengolahannya terbatas karena berbenturan dengan kepentingan masyarakat.

Melalui analisis terhadap setting fisik, dapat diketahui bahwa setelah menjadi kampung kreatif, Kampung Dago Pojok menjadi lebih hidup, dimana terdapat berbagai kegiatan yang bervariasi di luar aktivitas dasar masyarakat. Selain itu secara fisik, kampung menjadi lebih menarik dengan sentuhan karya kreatif yang membentuk citra baru dan rasa memiliki dalam diri masyarakat. Sehingga pada akhirnya kampung menjadi lingkungan rumah yang memberi peluang masyarakat untuk berkembang.

\section{DAFTAR PUSTAKA}

Ashihara, Yoshinobu. (1981). Exterior Design in Architecture. New York: Van Nostrand Reinhold Company.

Barker, R. G. (1968). Ecological Psycology: Concept and Methods for Studying the Environment of Human Behavior. Standford: Standford University Press.

Ching, Francis D.K. (2007). Arsitektur: Bentuk, Ruang, dan Tatanan. Jakarta: Erlangga.

Gehl, Jan. (1987). Life Between Buildings: Using Public Space. New York: Van Nostrand Reinhold Company.

Laurens, Marcella. Jonce,2004. Arsitektur dan Perilaku Manusia. Jakarta: Penerbit. PT Grasindo.

Rapoport, A. (1982). The Meaning of the Built Environment. SAGE Publications.

Kent, Susan (1990). Domestic Architecture and The Use of Space. Virginia: Cambridge University Press.

Widjaja, Pele. (2013). Kampung-Kota Bandung. Bandung: Graha Ilmu.

Gibbons, Zeynita. (2015). UNESCO Umumkan Bandung Masuk dalam Jaringan Kota Kreatif. 
Tersedia: http://www.antaranews.com/berita/ 534718/unesco-umumkan-bandung-masukdalam-jaringan-kota-kreatif, [17 Februari 2016].

Kamus Versi Online. Tersedia: http://kbbi.web.id/pustaka. [9 Februari 2016].

Safira. (2012). Kampung Kreatif. Tersedia: http://lib.ui.ac.id/file?file=digital/ 20308613-S\%2042588Kampung\%20kreatif-full\%20text.pdf. [22 Februari 2016].

Simbolon, Huyogo. (2016). Membangun Bandung dengan Daya Kreatif. Tersedia: https://beritagar.id/artikel/laporan-khas/membangun-bandung-dengan-daya-kreatif. [17 Februari 2016].

Yoga, Krisna. (2015). Setting Perilaku. Tersedia: http://archpopspot.blogspot.co.id/ 2015/10/setingprilakubehavior-setting.html. [10 Februari 2016]. 